\title{
Tiny Actors in the Big Cellular World: Extracellular Vesicles Playing Critical Roles in Cancer
}

\author{
Ancuta Jurj ${ }^{1, \dagger}$, Cecilia Pop-Bica ${ }^{1, \dagger}$, Ondrej Slaby ${ }^{2,3}$, Cristina D. Ştefan ${ }^{4}$, William C. Cho ${ }^{5}(\mathbb{D}$, \\ Schuyler S. Korban ${ }^{6}(\mathbb{D})$ and Ioana Berindan-Neagoe ${ }^{1,7, *(\mathbb{D})}$ \\ 1 Research Center for Functional Genomics, Biomedicine and Translational Medicine, "Iuliu Hațieganu” \\ University of Medicine and Pharmacy, 400337 Cluj-Napoca, Romania; ancajurj15@gmail.com (A.J.); \\ cecilia.bica8@gmail.com (C.P.-B.) \\ 2 Central European Institute of Technology, Masaryk University, 62500 Brno, Czech Republic; \\ on.slaby@gmail.com \\ 3 Department of Pathology, Faculty Hospital Brno and Faculty of Medicine, Masaryk University, 62500 Brno, \\ Czech Republic \\ 4 SingHealth Duke-NUS Global Health Institute, Singapore 169857, Singapore; cristinastefan10@gmail.com \\ 5 Department of Clinical Oncology, Queen Elizabeth Hospital, Hong Kong, China; chocs@ha.org.hk \\ 6 Department of Natural Resources and Environmental Sciences, University of Illinois at Urbana-Champaign, \\ Urbana, IL 61801, USA; korban@illinois.edu \\ 7 Department of Functional Genomics and Experimental Pathology, “Prof. Dr. Ion Chiricuta” Oncology \\ Institute, 400015 Cluj-Napoca, Romania \\ * Correspondence: ioananeagoe29@gmail.com \\ + These authors contribution equally.
}

Received: 26 August 2020; Accepted: 15 October 2020; Published: 17 October 2020

\begin{abstract}
Communications among cells can be achieved either via direct interactions or via secretion of soluble factors. The emergence of extracellular vesicles (EVs) as entities that play key roles in cell-to-cell communication offer opportunities in exploring their features for use in therapeutics; i.e., management and treatment of various pathologies, such as those used for cancer. The potential use of EVs as therapeutic agents is attributed not only for their cell membrane-bound components, but also for their cargos, mostly bioactive molecules, wherein the former regulate interactions with a recipient cell while the latter trigger cellular functions/molecular mechanisms of a recipient cell. In this article, we highlight the involvement of EVs in hallmarks of a cancer cell, particularly focusing on those molecular processes that are influenced by EV cargos. Moreover, we explored the roles of RNA species and proteins carried by EVs in eliciting drug resistance phenotypes. Interestingly, engineered EVs have been investigated and proposed as therapeutic agents in various in vivo and in vitro studies, as well as in several clinical trials.
\end{abstract}

Keywords: extracellular vesicles; cancer; therapeutic agents; cell-to-cell communication

\section{Introduction}

Both solid and hematological malignant tumors are not isolated entities. In fact, they involve complex systemic networks involving cell-to-cell communications between tumor cells and accompanying modified cells. Moreover, both tumor progression and invasion are sustained by a complex microenvironment. This is comprised of networks of components, including cancer-associated fibroblasts, endothelial cells, lymphocytes, and macrophages, as well as secreted factors and elements of the extracellular matrix. Interactions among neighboring cells through a direct cell-cell contact is essential for tumor growth and development, while intercellular communication provides a complex system of secreted factors [1]. 
To manage all components present in multicellular organisms, cellular communication is critical. McCrea et al. wrote an inspirational quote on the intercellular communication "the music that the nucleus hears" [2]. Communication involves sharing of information through several signaling mechanisms that are either direct (intracrine/autocrine and juxtacrine) and/or indirect (endocrine, paracrine, and synaptic) communications [3]. In this regard, all types of cells have been shown to release and receive both soluble factors and membrane-derived vesicles, the latter receiving increasing attention in the past decades [4]. The first instance of the presence of membrane-derived vesicles is observed in reticulocytes, wherein released vesicles would remove transferrin receptors from the cell, an important step in their maturation to erythrocytes [5]. Early on, these membrane-derived vesicles have been initially deemed as cellular "garbage bags". Subsequently, numerous studies have been undertaken to investigate membrane-derived vesicles detected on primary cells [6]; i.e., primary cells of the immune and nervous systems, and cancer cell lines [7]. It has been reported that extracellular vesicles (EVs) can be isolated from various bodily fluids, as they play important roles in the management of various normal physiological processes, including stem cell maintenance [8], immune surveillance [9], tissue repair [10], and blood coagulation [4].

It is reported that physical and molecular characteristics of EVs have impacts on various biological processes, including cancer development, progression, and metastasis [11]. Moreover, small sizes of EVs offer critical properties, including immune system escape, biocompatibility, and biodegradability, as well as transfer of their contents into both neighboring and distant cells. During biogenesis, EVs acquire important bioactive molecules that regulate several biological processes. Thus, cancer-derived EVs have been largely described as possessing both pro- and antitumor functions. For example, tumor-derived EVs interact with immune cells by delivering negative signals and interfering with their antitumor functions. By suppressing immune cell functions, EVs promote cancer progression and facilitate tumor escape. Moreover, EVs carry important molecules and factors that either directly or indirectly influence several processes, including development and maturation, as well as antitumor activities in immune cells [11]. Conversely, antitumor effects of EVs have been observed in dendritic cell-derived EVs, and these are capable of being used in immunotherapy [12].

It has been observed that EVs are tightly linked to tumorigenesis [13], spread of pathogenic agents and viruses (e.g., the Human Immunodeficiency Virus-1 [HIV-1]), amyloid- $\beta$-derived peptides [14], and $\alpha$-synuclein [15] (linked to Alzheimer's and Parkinson's diseases). Due to varied compositions of EVs, they have been deemed useful in the fields of both diagnostics and therapeutics [16]. Moreover, EVs can be potentially useful in serving as drug delivery vehicles by transporting several molecular species as part of normal cell-to-cell communication.

In this review, we will discuss the potential and role(s) of EVs in modulating both physiological and pathological processes, as well as how these entities can be used as therapeutic agents [17].

\section{The War Waged Inside the Cell}

EVs are described based on their size, cellular origin (endosome- or plasma membrane-derived), biological function, and biogenesis process. Moreover, when described based on their biogenesis, EVs are cataloged into apoptotic bodies, microvesicles, and exosomes [18]. These major classes are cell-based vesicles having diameters ranging between 30 and $2000 \mathrm{~nm}$ (Table 1). Furthermore, these entities exhibit different properties that help distinguish them among all main classes of EVs. Differences among different EV classes are based on the content, size, route of biogenesis, and surface markers [19].

One of the largest cell-based vesicles is those of apoptotic bodies that are released by any type of cell once apoptotic processes are activated. Specifically, apoptotic EVs are generated during plasma membrane blebbing during apoptosis, as these are phagocytosed by macrophages and then fused with lysosomes [20]. Generally, these EVs are known to carry nuclear fragments and cellular organelles as a result of cell fragmentation [20]. Furthermore, these EVs are characterized by a flip of phosphatidylserine along an external layer, a permeable membrane, and expression of phagocytosis-promoting signals (calreticulin [21] and calnexin [22]), as well as chemokines and adhesion molecules, including ICAM3 
and CX3CL1/fractalkine, and MHC class II molecules [23]. These are all important for direct antigen presentation CD4+ T cells and immunological memory activation [23].

Microvesicles, also known as ectosomes, are usually larger than $0.2 \mu \mathrm{m}$ in size, and they are released outward from the plasma membrane via budding or shedding into the extracellular matrix. The process of microvesicle formation is mediated through a complex process involving cytoskeletal protein contraction and phospholipid redistribution [24]. During biogenesis, microvesicles are mainly composed of a plasma membrane and of cytosolic-associated proteins [19]. Microvesicles are involved in several key functions, including intercellular communication, signal transduction, and immune regulation. In particular, these entities mediate tumor invasion, inflammation, metastases, stem-cell renewal, and expansion [25]. During biogenesis, microvesicles receive important structural components, including Flotillin-2, Annexin V, integrins, selectin, CD40, and metalloproteinase [26].

In contrast, exosomes are between $30-100 \mathrm{~nm}$ in size, and are generated using the endosomal pathway [25]. Exosome biogenesis begins with the formation of early endosomes that undergo inward (or reverse) budding and then subsequent formation of intraluminal vesicles (ILVs), and referred to as multivesicular bodies (MVBs) or late endosomes. As a final step, late endosomes may either directly fuse with lysosomes, wherein the endocytosed cargo is degraded, or they may fuse with the plasmalemma releasing its ILVs (exosomes) to the extracellular space [25,27]. ESCRT (endosomal sorting complexes required for transport) is a molecular complex that plays an important role in MVB formation and regulation (Figure 1). Specifically, ESCRT is formed from the other four molecular complexes, including ESCRT-0,-I, -II, and -III. These multi-protein complexes are responsible for different functions, depending on their components. ESCRT-0 is dependent on ubiquitin and determines clustering of the cargo, ESCRT-I and ESCRT-II play important roles in bud formation, and ESCRT-III determines scission of vesicles. In addition, accessory proteins (VPS4 ATPase) are implicated in the final steps of ESCRT functions, namely of dissociation and recycling. In many studies, other ESCRT-independent pathways of MVB formation have been observed [28]. Some classes of molecules implicated in ESCRT-independent mechanisms of exosome biogenesis are represented by proteolipid proteins, tetraspanins, and heat shock proteins [29].

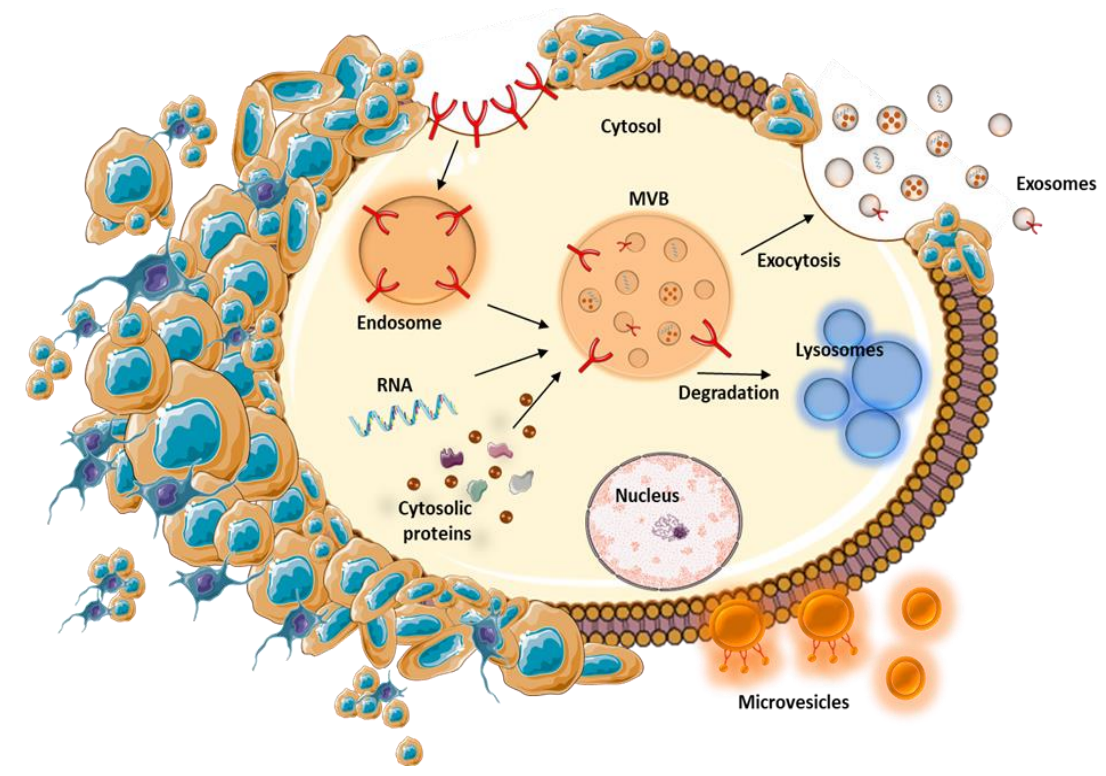

Figure 1. Biogenesis mechanisms of EVs, exosomes, and microvesicles. Endocytosis, an active process, begins with the generation of endosomes after cells are internalized within the extracellular fluid material to form internal vesicles and early and late endosomes. Furthermore, multivesicular bodies (MVBs) are formed via inward budding of a late endosomal membrane. Moreover, MVBs can fuse with either the plasmalemma, releasing their cargo into extracellular space, or with lysosomes, wherein their contents are degraded. 
In general, following MVB fusion with the plasmalemma, exosomes are secreted from cells. This mechanism is regulated via two mechanisms, constitutive and inducible. The constitutive mechanism is managed by a plethora of molecules, including heterotrimeric G-proteins, flotillins, and glycosphingolipids [30], while inducible secretion is determined by stress stimuli, including thrombin, DNA damage, hypoxia, heat shock, and lipopolysaccharide (LPS) stimulation [27].

Table 1. Major characteristics of EVs.

\begin{tabular}{|c|c|c|c|c|}
\hline Characteristics & Exosome & Multivesicular Body & Apoptotic Body & References \\
\hline Size & Homologous $30-100 \mathrm{~nm}$ & Heterogenous 100-1000 nm & Heterogenous $1-5 \mu \mathrm{m}$ & [31-33] \\
\hline Origin & $\begin{array}{l}\text { Multivesicular bodies fusion } \\
\text { with cellular membrane }\end{array}$ & $\begin{array}{l}\text { Direct outward budding or } \\
\text { blebbing from the cellular } \\
\text { membrane }\end{array}$ & $\begin{array}{c}\text { Cellular membrane blebbing } \\
\text { during cell death, cellular } \\
\text { debris }\end{array}$ & {$[33,34]$} \\
\hline Density & $1.13-1.19 \mathrm{~g} / \mathrm{mL}$ & $1.25-1.30 \mathrm{~g} / \mathrm{mL}$ & $1.16-1.28 \mathrm{~g} / \mathrm{mL}$ & [35] \\
\hline Contents & $\begin{array}{l}\text { Nucleic acids (DNA, } \\
\text { mRNAs, miRs), lipids, } \\
\text { specific proteins }\end{array}$ & $\begin{array}{l}\text { Nucleic acids (DNA, } \\
\text { mRNAs, miRs), lipids, } \\
\text { specific proteins }\end{array}$ & $\begin{array}{c}\text { Cellular organelles, cytosolic } \\
\text { content (RNAs, fragmented } \\
\text { DNA, proteins) }\end{array}$ & [33] \\
\hline $\begin{array}{l}\text { Protein } \\
\text { components }\end{array}$ & $\begin{array}{c}\text { Multivesicular body } \\
\text { biogenesis (ALIX, TSG101), } \\
\text { tetraspanins (CD9, CD63, } \\
\text { CD81, CD82) }\end{array}$ & $\begin{array}{l}\text { Death receptors (CD40 } \\
\text { ligands), Cell adhesion } \\
\text { (selectins, integrins) }\end{array}$ & $\begin{array}{l}\text { Transcription and protein } \\
\text { synthesis (histones) }\end{array}$ & {$[25,36]$} \\
\hline Lipids & $\begin{array}{l}\text { Lipidic molecules from the } \\
\text { donor cells (include BMP) }\end{array}$ & $\begin{array}{l}\text { Lipids from plasma } \\
\text { membrane and resemble the } \\
\text { donor cells (without BMP) }\end{array}$ & $\begin{array}{l}\text { Characterized by } \\
\text { phosphatidylserine } \\
\text { externalization }\end{array}$ & {$[36,37]$} \\
\hline $\begin{array}{l}\text { Mechanism of } \\
\text { release }\end{array}$ & $\begin{array}{l}\text { Constitutive and/or cellular } \\
\text { activation, depends on the } \\
\text { cell type of origin }\end{array}$ & $\begin{array}{c}\text { Cytoskeleton } \\
\text { rearrangements, generation } \\
\text { of membrane curvature, } \\
\text { vesicle release, relocation of } \\
\text { phospholipids to the outer } \\
\text { membrane }\end{array}$ & $\begin{array}{l}\text { Rho-associated kinase I and } \\
\text { myosin ATPase activity }\end{array}$ & [37-39] \\
\hline $\begin{array}{l}\text { Determinant of } \\
\text { controlled contents }\end{array}$ & $\begin{array}{c}\text { The cellular origin and } \\
\text { physiological state of the cell }\end{array}$ & No direct correlation & $\begin{array}{l}\text { The cellular origin and } \\
\text { stimuli }\end{array}$ & [35] \\
\hline Markers & $\begin{array}{c}\text { Membrane impermeable (PI } \\
\text { negative), CD63, TSG101, } \\
\text { Alix, flotillin, tetraspanins, } \\
\text { HSP70, HSP90 }\end{array}$ & $\begin{array}{l}\text { Membrane impermeable (PI } \\
\text { negative), selectin, integrin, } \\
\text { flotillin-2, Annexin A1 }\end{array}$ & $\begin{array}{c}\text { Membrane permeable (PI } \\
\text { positive), histone, DNA, } \\
\text { Annexin V }\end{array}$ & {$[25,32]$} \\
\hline
\end{tabular}

During biogenesis, exosomes receive critical bioactive molecules from donor cells, including nucleic acids, lipids, and proteins, that are specific for each cell type [40]. For composition of both exosomes and microvesicles, the following components are important: mRNAs, microRNAs (miR), non-coding RNAs, DNAs (mtDNA, ssDNA, and dsDNA), mRNA cytoplasmic proteins, and lipid raft-interacting proteins (Figure 2) [41]. Recent attention has focused on understanding how DNAs are packaged within EVs. In this regard, several research groups have reported on the presence of DNAs (mtDNA, ssDNA, and dsDNA) in EVs secreted from various types of malignancies, including melanoma, breast, lung, pancreas, and prostate cancer [42]. However, there is little knowledge of the origin, biological significance, and mechanism of DNA packaging in EVs. Conversely, few studies have reported that DNA is located along the outer surface and not within EVs [43,44]. Thus, it is proposed that outer surfaces of EVs are capable of interacting with proteins, nucleic acids, and other molecules regulating motility, aggregation, and various other important processes for EVs [45]. Furthermore, cargos within these vesicles can influence recipient cells [46], thus suggesting that exchanges of EV cargos between either normal or cancer cells may represent an effective and efficient intercellular communication when cells have particular physiological behaviors, but these are dramatically altered in cancer cells. Alongside nucleic acids, exosomal proteins are specific, and they are present in endocytic compartments of donor cell membranes, as well as in cellular membranes, the nucleus, the cytosol, and the Golgi apparatus, as well as in the endoplasmic reticulum and mitochondria, but at lower frequencies for these latter two organelles [47]. Tetraspanins (CD9, CD63, CD81, and CD82) are among some of the most typical proteins present in exosomes, alongside GPI-anchored proteins 
and receptors. Moreover, within interiors of exosomes, several molecular species of a parent cell are encased, and these are represented by structural components, heat shock proteins, chaperones, and enzymes involved in metabolic processes, among many others (Figure 2) [17,27].
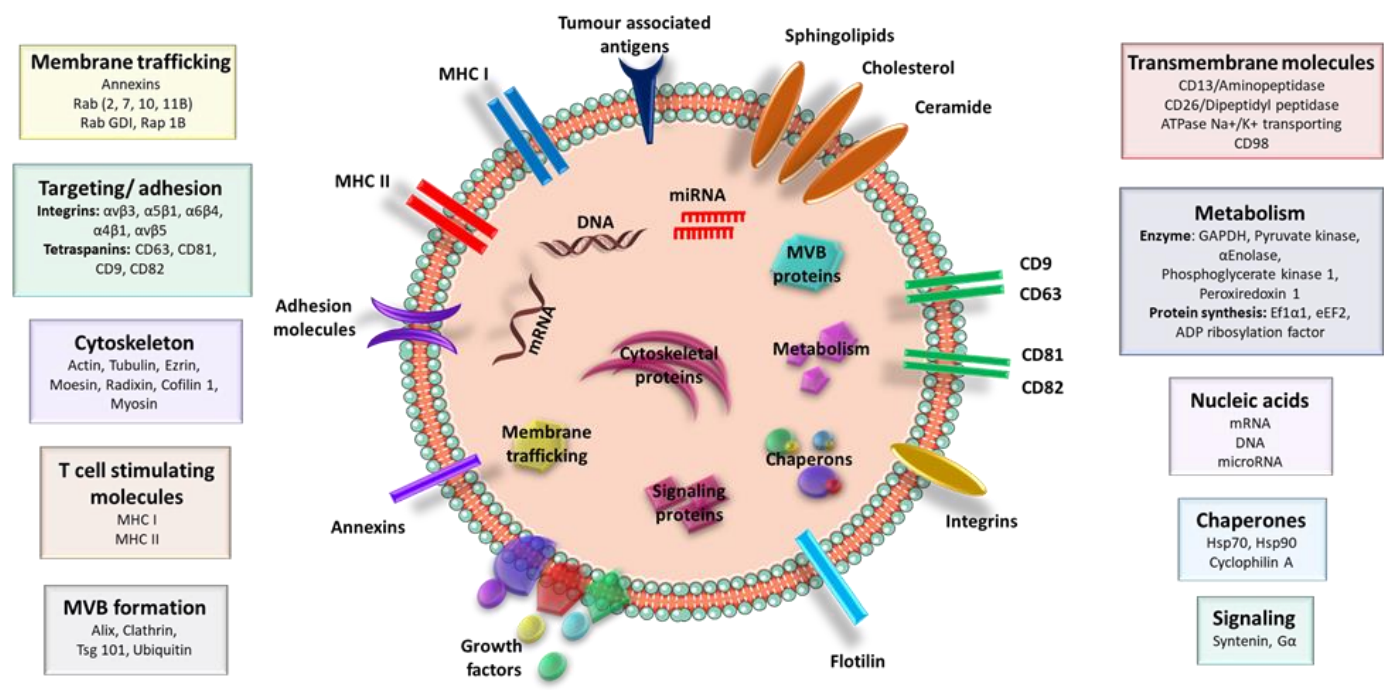

Figure 2. EVs' cargo profile. EVs are secreted by a wide range of cells, normal and tumor, having the capacity to deliver various bioactive molecules including nucleic acids, specific proteins, and lipids from the donor cells to recipient cells

Interestingly, EVs are carriers of essential soluble immune mediators, including cytokines and chemokines. Several cytokines, such as IL-1 $\alpha$, IL-1 $\beta$, IL-6, IL18, and IL-32, are engulfed within EVs. In endothelial cell-derived apoptotic bodies, IL-1 $\alpha$ is present; whereas, IL-18 is associated with EVs shed from surfaces of macrophages. Additionally, IL-6 and IL-32 are secreted by mast cells upon IL-1 stimulation [48]. Moreover, heat-stressed tumor cells have been shown to release EVs with different CCL compositions compared to their nonstressed counterpart [49].

\section{EVs Isolation and Characterization}

EVs can be isolated from different biological fluids (plasma, serum, saliva, milk, and urine, among others), as well as from cell culture supernatants. There are several available methodologies to remove undesirable particles from samples of interest. In cell cultures, EVs are separated from other components of cell media using differential centrifugation. This technique utilizes centrifugal force to separate contaminants from EVs, along with several necessary steps to remove cells, cell debris, and large microvesicles in order to obtain purified EVs [50]. Another isolation technique, density gradient centrifugation, separates EVs into specific layers in different solutions (sucrose, iohexol, and iodixanol) depending on their buoyant densities [51]. In this method, subcellular components, including mitochondria, endosomes, and peroxisomes, are successfully separated into distinct layers within the density gradient solution [52]. In yet another method, size-exclusion chromatography utilizes porous beads to separate biomolecules based on their hydrodynamic radii [53]; thus, biological samples are filtered through a column of porous beads of radii smaller than those of EVs [54]. Similarly, filter-based enrichment methods also depend on the sizes of EVs for separation, but instead of porous beads, sieves are used. Further, antibody enrichment methods are based on selecting for markers specific for EVs, such as CD9, CD63, and CD81, thus serving as complementary to size-based methods, thereby capable of specific selection of EVs [55]. Recently, acoustics and/or microfluidics methods have been developed that will isolate EVs in label-free and contact-free manners [56,57]. In addition, EVs can be separated from biological samples via precipitation using different chemicals, such as polyethylene glycol (PEG), sodium acetate, or protamine. It has been reported that using PEG, both EVs and proteins are precipitated into a pellet that can be further analyzed [58]. Similarly, magnetic beads coated with 
antibodies for common EV surface proteins (CD9, CD63, and CD81) are used [59]; whereas, a fluidic technique, ExoTIC (exosome total isolation kit), utilizes step-wise nanoporous membranes to trap molecules or particles of specific sizes, thereby allowing for smaller molecules and particles to flow through a membrane filter [60]. This latter method may be deemed as the most accurate size-based method used to isolate EVs from biological samples with a high yield of intact EV structures.

As EVs, of nano-sizes, must be quantified and evaluated for purity, there are several methods that can determine the numbers of vesicles released and cell type (detection of surface antigens), as well as EV morphological traits [61]. Dynamic light scattering (DLS) is based on a particle's Brownian motion in solution, used to measure the size distribution of particles, as well as their zeta potentials, measuring diameters of particles ranging between $1 \mathrm{~nm}$ and $6 \mu \mathrm{m}$ [62]. However, this technique does not provide any biochemical data of purified EVs [62]. In another technique similar to DLS, nanoparticle tracking analysis (NTA) is used to measure concentration, count, and size distribution of EVs based on their Brownian motion; moreover, this technique can measure smaller-sized EVs, ranging from 1 to $1000 \mathrm{~nm}$ [63]. In yet another technique, flow cytometry is used to indirectly quantify EVs as it is based on using specific antibodies that accurately recognize EV markers from a liquid medium. However, flow cytometry cannot evaluate the complex profiles of subsets of EVs. Similar to DLS and NTA, flow cytometry is capable of providing data on EV size, count, and distribution [64]. Finally, both EV purity and quality can be determined using transmission electron microscopy (TEM) wherein standard traits, such as cup-like structures and lipid bilayers, can be determined [65]; whereas, EV purity can be assessed based on presence or absence of protein markers [50].

\section{Biological Roles of EVs}

EVs, particularly exosomes, play important roles in cells by influencing several biological processes. Their effects on receptor cells can be exerted via various mechanisms, such as phagocytosis, direct receptor binding, and receptor-dependent internalization. Thus, EVs can deliver information through a wide range of mechanisms, thereby playing important roles in tissue repair [10], stem cell maintenance [8], and immune surveillance [9]. Due to their pleiotropic actions, EVs have been, time and time again, deemed as signalomes.

It has been reported that EVs can influence activities of immune cells present both in the tumor microenvironment and in the circulatory system [66]. Once EVs are internalized into targeted cells, they release their cargo and exert their role by activating different biological mechanisms. EVs can mediate the activation of immune cells by promoting proliferation and survival of hematopoietic stem cells, as well as activation of monocytes [67], B lymphocytes [66], and NK cells [68]. EVs can also inhibit immune responses via regulation of NK and CD8 ${ }^{+}$cell activities [69] and activation of Treg cells, as well as inhibition of dendritic cell (DC) maturation [70] and formation [71]. For those EVs derived from stem cells, they have been demonstrated to regulate stem cell maintenance with implications in tissue regeneration [72]. In addition, it has also been shown that EVs can modify stem cells to develop into either a liver cell phenotype [73] or a lung phenotype [74].

\section{Pathological Roles of EVs}

It is important to point out that EVs can be secreted by malignant or deregulated cells. During biogenesis processes, EVs are loaded with important bioactive molecules from malignant cells that influence the phenotype(s) of target cells. It has been reported that EVs are implicated in the formation of a premetastatic milieu throughout the body [75]. Moreover, EVs are also involved in other critical biological processes and have the capability of stimulating tumor progression [13]. This process is sustained by EVs via delivery and release of their targets into a target cell(s). Alongside tumor progression, EVs have the capability of carrying out other critical processes, including cell proliferation, tumor growth [76], angiogenesis [77-85], matrix remodeling, metastasis [75,86-96], immune escape [69,97-109], resistance to apoptosis [110-113], deregulation 
of energetic metabolism [114-117], sustaining proliferative signaling [94,118-120], evading growth suppression [121-123], deregulating and tumor-promoting inflammation [100,124,125] (Figure 3).

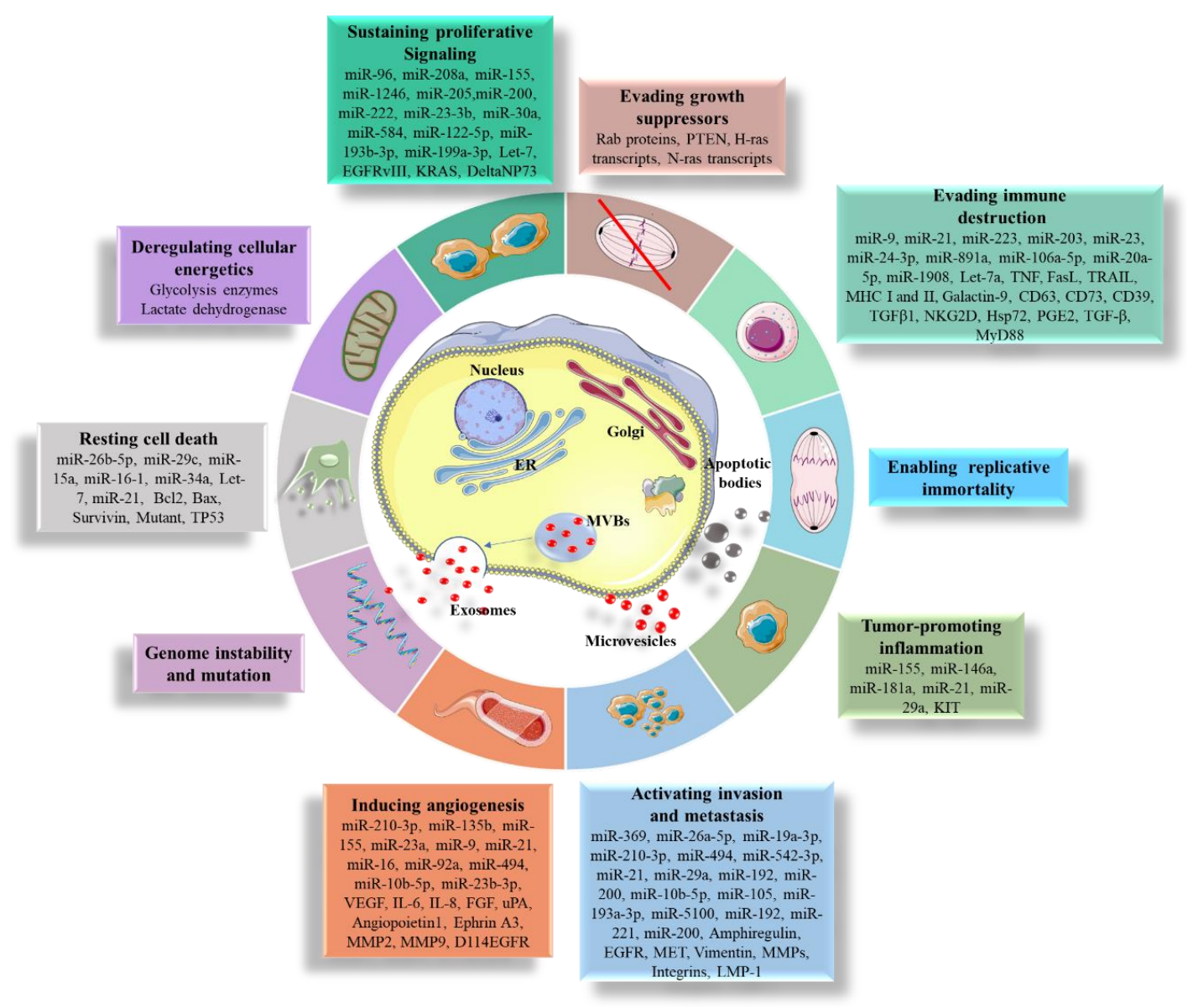

Figure 3. A schematic representation of the impact of tumor-derived EVs on the hallmarks of cancer. Pro-oncogenic molecules can be transported through the cellular membrane by EVs and microvesicles. Molecules transported via EVs have been reported to contribute to each of the hallmarks of cancer. Abbreviations: ER, endoplasmic reticulum; MVBs, multivesicular bodies

\subsection{Promoting Cell Proliferation and Resistance to Apoptosis}

EV transfer can modify particular signaling pathways in the target cell, modifying proliferation and resistance to apoptosis, among other processes. For example, it has been reported that in gastric cancer, cell proliferation can be enhanced through exosomal transfer of CD97 that activates the Mitogen-Activated Protein Kinase (MAPK) pathway [126]. In chronic myeloid leukemia, it has been observed that cellular proliferation is promoted via induction of phosphatidylinositol 3-kinase (PI3K)/protein kinase B (AKT) and MAPK pathways [127]. For instance, melanoma-derived EVs transfer PDGFR-8, which in turn activates the PI3K/AKT pathway in target cells [128]. Moreover, PI3K/AKT and MAPK pathways are reported to be activated in both gastric and bladder carcinomas by EVs [129]. In addition, EVs derived from glioblastoma are reported to promote cell proliferation in a CLIC1-dependent manner [130]. Soekmadji et al. have demonstrated that EVs derived from prostate cancer cells cultured in the presence of androgens are enriched in CD9, which promotes proliferation of androgen-deprived cells [131]; whereas, Matsumoto et al. have reported that mice injected with melanoma-derived EVs result in accelerated in vivo growth of murine melanomas [132].

EVs can also alter target cell(s) via their miR content as it has been shown that miR-93-5 from esophageal cancer-derived EVs inhibits phosphatase and tensin protein (PTEN) expression stimulating cell proliferation [133]. Other important examples of EVs' role in stimulating cell proliferation has 
been reported in colon cancer wherein EVs carry higher levels of miR-200b and miR-193a [134] and of pancreatic cancer-derived EVs loaded with miR-23b-3p and of papillary thyroid cancer-derived EVs loaded with miR-222 [135]. Furthermore, it has been observed that tumor-derived EVs actively transfer miR-106a-5p, miR-891a, miR-24-3p, and miR-20a-5p that promote cell proliferation via alteration of Microtubule Affinity-Regulating Kinase1 (MARK1) signaling in human nasopharynx cancer [136]. Moreover, EV miR-302b is delivered from lung carcinoma cell lines to target cells, leading to cell growth inhibition via the TGF $\beta$ RII/ERK signaling pathway [137], while EV miR-584 accelerates cell proliferation in hepatocellular cancer cells [138].

\subsection{Promoting Cell Migration}

In addition to their effects on cell proliferation, EVs secreted by tumor cells can also alter the migratory status of malignant cells. EVs derived from nasopharyngeal carcinoma carrying epithelial-mesenchymal transition (EMT)-inducing signals, including HIF1 $\alpha$, TGF $\beta$ [98], and matrix metalloproteinases (MMPs), were reported to improve the migratory capacity of tumor cells [139]. Interestingly, EVs from a hypoxic prostate cell line have been shown to lead to increased mobility and invasiveness in a naïve human prostate cancer cells [140]. Moreover, EVs secreted from muscle-invasive bladder cancer contributed to decreased levels of E-cadherin as well as to enhanced migration and invasion in uroepithelial cells [141,142]. In another study, EV miR-105 was reported to stimulate invasion in both the respiratory and central nervous systems by inhibiting ZO-1 in endothelial cells, leading to enhanced cell migration [143]. Furthermore, it has been observed that EV miR-21 stimulates invasion of esophageal tumor cells by activating the programmed cell death 4 (PDCD4)/ c-Jun $\mathrm{NH}_{2}$-terminal kinase (JNK) axis [90].

\subsection{Sustaining Angiogenesis}

It has been reported that induction of a mutated epidermal growth factor receptor variant III (EGFRvIII) in glioma cells would lead to increased vesiculation and transfer of the mutated EGFRvIII to other cells and to increased vascular endothelial growth factor (VEGF) production [94]. In addition, it has been observed that EVs from primary glioblastoma cells are loaded with miRs that influence angiogenesis [76]. Recently, it has been demonstrated that EGFR can be transferred to endothelial cells wherein expression of VEGF is induced along with subsequent autocrine activation of VEGF-R2 [77]. Thus, these findings suggest that EVs can result in tumor growth by stimulating cancer cell proliferation and activating angiogenesis in adjacent endothelial cells [77]. Kim et al. have reported that sphingomyelin expressed on tumor cells-derived EVs stimulate processes, such as migration and angiogenesis, in endothelial cells [144]. It has been observed that such EVs secreted by tumor cells are enriched in MMPs as well as in CD147. These components have been proposed to play roles in both hydrolysis of the extracellular matrix and initiation of angiogenesis [145]. Interestingly, it has also been observed that PSTAT5 can be transferred to endothelial cells via EVs, and that it is capable of activating ERK1/2 along with subsequent angiogenesis stimulation [146]. Moreover, miR-214 is also responsible for promoting angiogenesis by suppressing Ataxia Telangiectasia Mutated (ATM) expression and preventing senescence [147]. In fact, mesenchymal stem cells-derived EVs have also been shown to stimulate the angiogenesis process, as demonstrated in vivo in an ischemic heart model [148].

Colon cancer cells have been shown to transfer miR-25-3p to endothelial cells not only by stimulating angiogenesis but also by increasing vascular permeability [149]. EVs secreted by hepatocellular carcinoma cells have been shown to transfer miR-103 to endothelial cells, leading to a reduction in the integrity of endothelial junctions, and thereby increasing vascular permeability [150]. The angiogenesis process has also been shown to be stimulated by miR-145-5p and miR-14-3p from lung cancer-derived EVs [151]. Moreover, in lung cancer cells, release of EV miR-21 stimulates angiogenesis in nontumor lung cells [90]. In another study, miR-9 exhibits proangiogenic activity by reducing expression levels of the SOCS5 gene and by promoting Janus kinase/signal transducers and activators of transcription (JAK-STAT) signaling, thereby supporting migration of endothelial cells and 
tumor angiogenesis [152]. Furthermore, increased expression levels of EV miR-9 can differentiate an osteoblast precursor cell line into osteoblast cells and upregulate angiogenesis via an AMPK-dependent pathway [153].

From a therapeutic perspective, it has been observed that EVs can be used to shed bevacizumab, an anti-VEGF antibody, thus leading to decreased efficacy in glioblastoma [154]. Additionally, some cancers are capable of secreting VEGF isoforms with reduced affinities for bevacizumab, leading to another therapy escape mechanism [155]. Another antiangiogenic agent commonly used throughout the field of oncology is sorafenib. Hepatocellular carcinoma-derived EVs have been shown to activate the HGF/MET/AKT pathway in sensitive hepatocellular carcinoma cells, thereby inducing sorafenib resistance. Moreover, it has been observed that more invasive cell lines are capable of better inducing sorafenib resistance compared to less invasive cell lines, thus demonstrating that different malignant subclones are capable of sharing their acquired resistance [156].

It has been reported that sorafenib induces increased expression of linc-ROR in EVs secreted by hepatocellular carcinoma cells [157]. EVs have also been shown to transfer resistance to sunitinib, a similar compound to sorafenib, to hepatocellular carcinoma subclones [157], as well as to different subclones of renal cell carcinoma [158].

\subsection{Immune System Evasion}

One of the important functions of the immune system is to recognize and to destroy particular cells that present alterations when compared to self-antigens of unaltered (normal) cells. However, this function can be evaded by malignant cells either by changing surface antigens of malignant cells or by influencing the immune system. The role(s) of EVs in this process has been reported in various studies [80]. It has been demonstrated that EVs secreted from tumor-derived macrophages are enriched with particular miRs that enhance the local invasion of breast cancer cells [103]. In fact, the effects induced by EVs are related to modulation of the immune response. Furthermore, it has been demonstrated that EVs of tumor cells are capable of promoting immune escape by determining regulatory $\mathrm{T}$ cell expansion [159] and by shedding FAS ligand (FASL), as well as by inducing CD8 ${ }^{+} \mathrm{T}$ cell apoptosis and increasing expression of the MMP9 gene in melanoma cells $[79,160]$.

Recently, it has been reported that EVs can express PD-L1, thus suppressing activities of antitumor T-cells [161]. Moreover, it has been observed that EV PD-L1 expression is inversely correlated with nivolumab and pembrolizumab response [162]. These findings are of particular importance in checkpoint blockade therapy as this reveals that EVs can act as decoys for therapeutic agents. As checkpoint blockers, this would allow for adjustment of the dosage of therapy by taking into consideration EV expression of particular markers, such as PD-L1. In other cancers, such as head and neck squamous cell carcinoma, it has been observed that there are differences between EV cargos in patients experiencing relapse compared to those who remain in remission at two years following ipilimumab therapy [163]. More specifically, it has been observed that for patients in remission, at two years, have lower numbers of EVs positive for both CD3 and CTLA4. Conversely, it has been shown that patients who relapsed after two years have increased numbers of EVs derived from Treg cells, thus demonstrating the importance of EVs in mirroring the T-cell response to tumor cells [163].

Immunomodulatory effects of EVs have also been reported in gastric cancer [164]. It has been observed that EVs isolated from gastroepiploic veins have shown increased levels of TGF- $\beta 1$ expression for patients presenting either lymph nodes or distant metastasis. This finding has demonstrated the role of EVs in preparing an immunosuppressive premetastatic niche for engraftment of circulating tumor cells [164]. Although not explored in the abovementioned study, it is likely that checkpoint inhibitors could reverse these observed generated immunosuppressive premetastatic niches along with reduced probability of gastric cancer reaching advanced stages.

In other studies, it has been observed that EV miR-212-3p from pancreatic cancer cells have degraded RFXAP mRNAs in dendritic cells (DCs), leading to immune tolerance by minimizing expression of MHC II [165]. Furthermore, hypoxic tumor cells-derived EVs influence functions of 
natural killer (NK) cells by delivering miR-23a and TGF $\beta$ [166], while miR-214 secreted from human embryonic kidney cells induces immunological tolerance responses in CD4+ T-cells [167].

\subsection{Transferring Mutations}

Tumor-derived EVs have DNA fragments that can be transferred to recipient cells [45]. It has been reported that resistant melanoma cells can activate the MAPK pathway in sensitive melanoma cells through an EV-mediated truncated ALK transfer [168]. Moreover, EVs positive for EGFRvIII have been shown to activate both MAPK and PI3K/AKT pathways [94]; whereas, $\beta$-catenin-mutated colon cancer cells are reported to transfer their mutation to $\beta$-catenin wild-type cells along with subsequent activation of the $\beta$-catenin/WNT pathway [169]. In addition, a mutated SMAD4 is observed to be transferred from resistant to sensitive ovarian cancer cells, leading to an increased platinum resistance [80].

\section{EVs in Cancer Stem Cells}

As EVs play important roles in cancer cells, it is known that particular subpopulation(s) within a malignant mass, cancer stem cells (CSCs), present significant chemoresistance and are generally deemed as seeds for relapse [170]. EVs derived from CSCs are reported to transfer particular information to other cells. For example, EVs derived from renal cell carcinoma stem cells have been shown to carry a specific miR signature that influences levels of PTEN in target cells. This change is functionally translated into increased EMT followed by a subsequent increase in frequency of metastasis $[88,171]$.

EVs derived from glioblastoma stem cells contain miR-21, which can be transferred to endothelial cells, leading to upregulation of angiogenesis via the miR-21/VEGF pathway [172]. In another study, macrophages treated with glioblastoma cancer stem cell-derived EVs can skew macrophages to an anti-inflammatory phenotype (M2), associated with increased expression of PD-L1 on surfaces of these cells, thus demonstrating immunosuppressive roles of these EVs [173]. On the other hand, EVs from thyroid CSC spheroids can induce a stem cell-like phenotype in recipient cells by increasing levels of SOX2. Moreover, it has been shown that EVs derived from these cells also increase the EMT through SLUG upregulation [174].

EVs from CSCs have also been shown to influence the immune system, as EVs derived from colorectal CSC are reported to increase IL-1 $\beta$ in neutrophils, thereby inducing a pro-inflammatory environment [175].

\section{EVs in Drug Resistance}

One of the most heavily investigated characteristics of EVs is their ability to transfer resistance to particular therapeutic compounds. This is due to their capability of transferring specific molecular traits, such as efflux pumps or pathway regulation, thus rendering a phenotype better adapted to a particular selected therapeutic strategy [80]. Often, efflux pumps are transferred from resistant to sensitive cells [176-180]. These efflux pumps induce tumor resistance, corresponding to the transfer of ATP-binding cassette (ABC) family members, of which the multidrug resistance 1 (MDR1) and multidrug resistance-associated protein 1 (MRP1) have attracted attention in oncology [176-180]. More specifically, MRP1 can be transferred from resistant acute promyelocytic leukemia to sensitive cells [176]. Additionally, in breast cancer, MDR1 can be induced by EVs through the activation of NFATc3 [181]. On the other hand, it has been demonstrated that p-STAT3 can be transferred to 5-fluorouracil-sensitive colorectal cancer cells to increase their resistance to 5-fluorouracil [182]. Furthermore, it has been observed that CLIC1 can be transferred to gastric cancer cells, thereby increasing levels of MDR1 and BCL2 and leading both to increased drug efflux and decreased apoptosis [183].

It is important to point out that other important molecular species, including both coding and non-coding RNAs, can also be transferred in EVs, which can also contribute enhanced cell resistance to various drug/compound treatments. 
As platinum compounds are important components of the oncology arsenal, studies have been undertaken to assess transfer of resistance to these compounds. Often, it has been demonstrated that miRs influence resistance to platinum. For example, miR-19b influences resistance to platinum in colon cancer [184], while both miR-425-3p and miR-96 influence resistance to platinum in lung cancer cells $[185,186]$. Moreover, transfer of lncRNA HOTTIP increases resistance to platinum in gastric cancer cells, while increased serum HOTTIP lncRNA is associated with poor response to platinum [187]. Furthermore, coding RNAs are reported to influence sensitivity to platinum. For example, transfer of DNMT1 mRNA increases the resistance of ovarian cancer to platinum compounds [188].

Several other compounds are reported to be transferred through EVs as well For example, resistance to 5-fluorouracil in colon cancer cells is induced by both miR-145 and miR-34a [189], while the resistance of breast cancer cells to both adriamycin and tamoxifen are mediated by miR-222 transfer [190,191], and resistance of pancreatic cancer cells to gemcitabine is mediated by miR-155 transfer, leading to TP53INP1 modulation [192].

Interestingly, some pathways are more frequently targeted by some of the miRs, it has been reported that the PI3K/AKT pathway can be targeted by miR-21 in breast cancer cells [193] and by miR-1238 in glioblastoma cells [194].

\section{EVs Used as Diagnostic Markers}

EVs have been deemed as useful diagnostic markers in detecting the presence of a disease once the characteristics of malignancy are known. However, current methodologies for isolation and characterization of EVs are costly and not sufficiently standardized for de novo diagnostic protocols.

Nevertheless, one set of markers useful for diagnostics consists of fusion genes present in an assessed disease. These fusions occur more or less frequently depending on various malignancies, with hematologic malignancies, sarcomas, and prostate cancer presenting the most frequent fusion events [195]. For example, presence of $B C R-A B L$ fusion genes in EVs, secreted by chronic myelogenous leukemia (CML) [18], in a patient's plasma correlate with remission status in CML patients [196]. Although this approach cannot be directly transferred to a clinical diagnosis, as CML can be easily assessed in a patient's blood, this can serve as an example for use in solid tumors, such as prostate cancer. The prostate cancer malignancy presents gene fusions in $~ 50 \%$ of cases, particularly of the TMPRSS2-ERG fusion gene as it is highly frequent [197]. Such an approach requires use of urine samples as isolated EVs present alterations in RNA signature(s) compared to those of control samples, including presence of the TMPRSS2-ERG fusion gene [198].

However, several common cancers do not present high frequencies of fusion genes. As a result, alternative strategies must be explored. For example, HER2-HER3 dimers from EVs have been assessed in HER2-positive breast cancer patients participating in a clinical trial (NCT04288141). Although the primary objective of this study was to identify a marker for resistance to anti-HER2 therapy, assessment of HER2-HER3 dimers from EVs may aid in identifying the tumor load in HER2-positive breast cancer patients (NCT04288141).

One of the most common alternative approaches under consideration for use of EVs as biomarkers is that of the dosage of the RNA species, particularly of miRs, determined by qRT-PCR followed by protein assessment, using either ELISA or mass spectrometry [199]. However, a major problem that may arise, particularly in assessing RNAs content in EVs, is that of sensitivity of RNA species to particular transport and storage conditions. Moreover, it has been observed that RNA assessment has rarely made it to a clinical setting, as these assessments have been generally constrained to viral loads, particularly of RNA viruses.

Thus, future studies should focus on either genetic or proteomic markers present in EVs, as these are more likely to be amenable for clinical implementation. 


\section{EVs Used in Anti-Cancer Therapy}

In recent years, accumulated knowledge of characteristics and cargos of EVs has suggested that these structures could serve as valuable biomarkers for diagnostic/prognosis, as well as therapeutic agents for treatment of various pathologies [200]. The emergence of EVs in cancer therapy serves as a valuable nanotechnology to overcome major worldwide cancer management problems [201]. Currently, there are many studies recommending use of EVs as delivery vectors for treatment of various cancer, following manipulation and engineering of these EVs to carry various molecules useful as therapeutic agents (Figure 4) [61,202,203].

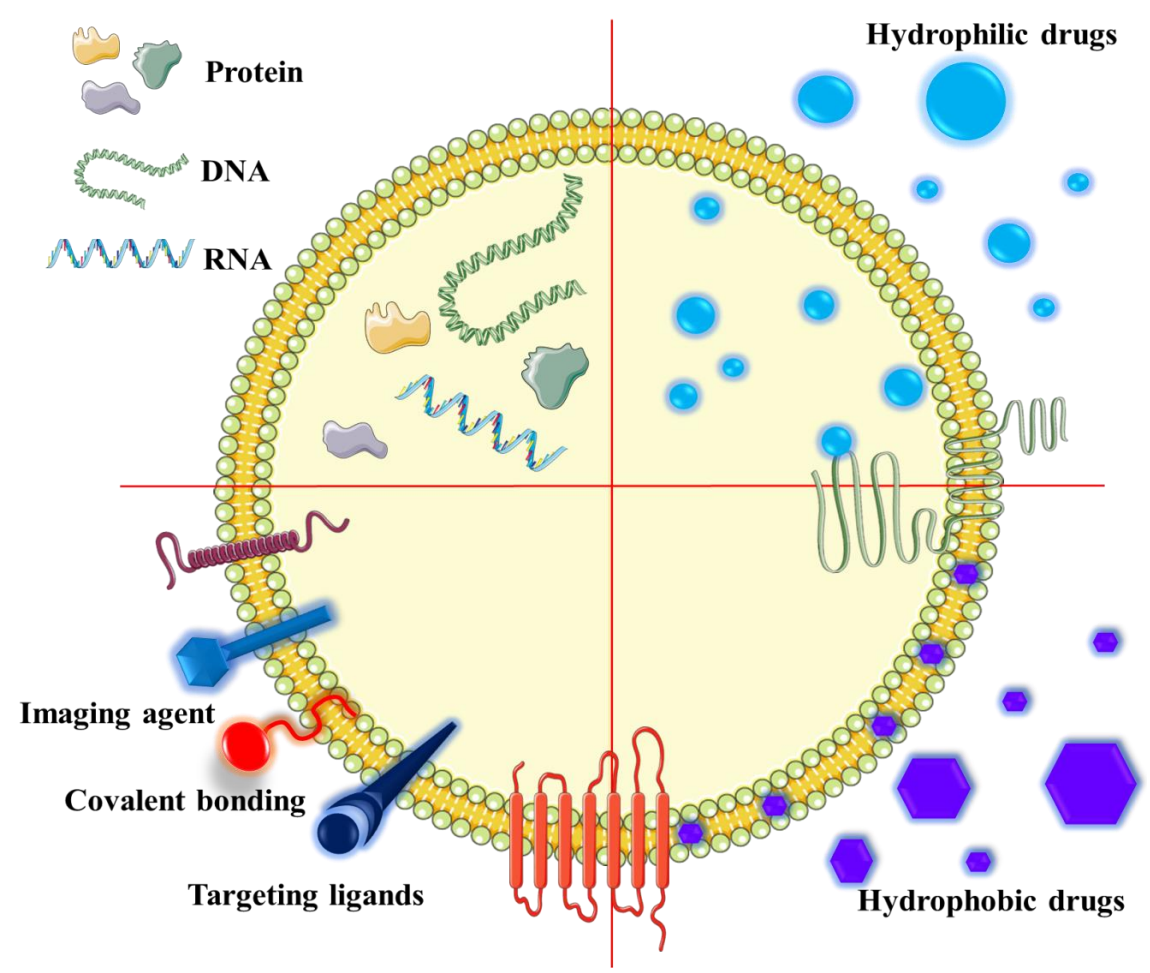

Figure 4. Properties of EVs useful in serving as drug delivery systems. These EVs consist of a lipid bilayer and an aqueous core, as they can incorporate hydrophilic drugs, hydrophobic drugs, nucleic acids (DNA, RNA), and proteins, as well as compounds (targeting ligands, covalent bonding, and imaging agents) that can be specifically attached to surfaces of EVs.

Overall, use of EVs as delivery agents will aid in the transport of internal cargo via enhanced endocytosis, thus protecting the contents from degradation. In contrast to liposomes or other nanoparticles used as carriers, EVs can serve as ideal bioparticles for targeted therapies [204,205]. Interestingly, it is suggested that biodistribution of EVs is influenced by cell origin and characteristics, with cell-specific tropism, thereby highlighting their potential use in the field of precision medicine [206]. In this arena, studies have reported on the efficiency of EVs as biocompatible drug vectors, as well as exhibiting low cytotoxicity and immunogenicity, and demonstrating their internalizing capabilities within a cell, as well as crossing the blood-brain barrier [207,208]. These EVs are capable of encapsulating various molecules, such as siRNA, miR, and various chemotherapeutics [207]. For example, Ma et al. have demonstrated that EVs carrying anti-cancer compounds can be absorbed by regenerated tumor cells, thus offering opportunities for their use in overcoming acquired drug resistance during cancer therapy [208]. Furthermore, it is reported that EVs are more likely to be internalized under acidic conditions; therefore, tumor cells are preferentially targeted by EVs rather than cells from surrounding healthy tissues [209]. Moreover, paclitaxel-loaded EVs have been used to improve the efficiency of treatment in multidrug-resistant tumor cells [210]. Recently, it has been demonstrated that tumor-derived EVs exhibit tropism toward their parental tumor cells [211], wherein engineered EVs, 
derived from fibrosarcoma and cervical cancer cell lines encapsulating the drug Doxil, are monitored both in vivo and in vitro using either HT1080 or HeLa tumors/cell lines. As expected, mice treated with Doxil-encapsulated EVs have higher levels of Doxil at the tumor site than those treated with Doxil alone, thereby reducing nonspecific cytotoxic effects of this drug [211].

In another study on small cell lung cancer (SCLC), sFlt-1-enriched EVs (soluble fms-like tyrosine kinase-1) are reported to act as tumor suppressors in mice via suppression of angiogenesis and induction of apoptosis in SCLC tumor cells [212].

Furthermore, in vitro and in vivo experiments of colorectal cancer cells revealed that EVs carrying miR-128-3p enhanced sensitivities to oxaliplatin by targeting Bmi1 and MRP5 genes [213]. In another study, the inhibitory effects on cell proliferation and EMT of miR-34c were evaluated using EVs derived from mesenchymal stem cells for delivery of miR-34c into nasopharyngeal carcinoma cell lines, and increased sensitivity to radiotherapy was observed [214]. Moreover, EVs delivering miR-199a-3p successfully suppressed both invasion and proliferation of ovarian cancer cell lines [215].

Currently, numerous clinical trials are investigating potential uses of EVs for either diagnostic/prognostic purposes or for therapeutic treatments of cancer (Table 2). These clinical trials assessing the use of microvesicles underlines their critical roles in malignancies. For example, some of these ongoing studies are evaluating engineered EVs for use as therapeutics for the treatment of pancreatic cancer. While in a completed phase II clinical trial, a vaccine developed with tumor antigen-loaded dendritic cell-derived EVs for NSCLC patients responsive to induction chemotherapy have yielded promising results [216]. It is reported dendritic cell-derived EVs manufactured with IFN- $\gamma$ serve as a viable immunotherapeutic for NSCLC patients [216]. Moreover, this construct boosts NKp30-dependent NK cell functions, but without adverse consequences on antigen-specific $\mathrm{T}$ cell responses when used as maintenance immunotherapy for these NSCLC patients [216].

Table 2. Clinical studies exploring the use of EVs in cancer research studies.

\begin{tabular}{|c|c|c|}
\hline Clinical Trial Identifier/Phase Status & Malignancy Investigated & EVs Use \\
\hline NCT03236675/active, not recruiting & NSCLC & Detection of $E M L 4-A L K$ fusion transcripts and T790M EGFR mutation \\
\hline NCT03108677/recruiting & Osteosarcoma & Biomarkers for lung metastases, based on the RNS profile \\
\hline NCT03985696/recruiting & Non-Hodgkin B-cell Lymphomas & $\begin{array}{l}\text { Investigate EVs roles in immunotherapy, as carriers of therapeutic targets } \\
\text { (CD20, PDL-1) }\end{array}$ \\
\hline NCT03217266/recruiting & Soft tissue sarcoma & Detection of cell-free circulating tumor DNA mutations. \\
\hline NCT02310451/unknown & Melanoma & Investigation of the effect of EVs produced by senescent melanoma cells \\
\hline NCT03800121/recruiting & Sarcoma & Biomarkers for recurrence. \\
\hline NCT03102268/unknown & Cholangiocarcinoma & Characterization of the ncRNAs in tumor derived EVs \\
\hline NCT03911999/recruiting & Prostate cancer & $\begin{array}{l}\text { Investigation of the relationship of urinary EVs and the aggressiveness of } \\
\text { prostate cancer }\end{array}$ \\
\hline NCT03711890/recruiting & Pancreatic cancer & Diagnostic biomarkers \\
\hline NCT02869685/unknown & NSCLC & Detection of PD-L1 mRNA in plasma EVs \\
\hline NCT03488134/active, not recruiting & Thyroid cancer & Urine exosomal proteins as biomarkers \\
\hline NCT04258735/recruiting & Breast cancer & Diagnostic makers in a genomic panel \\
\hline NCT02862470/active, not recruiting & Thyroid cancer & Urine EVs for the use as prognostic biomarkers \\
\hline NCT01159288/completed & NSCLC & Treatment as tumor antigen-loaded dendritic cell-derived EVs \\
\hline NCT04227886/recruiting & Rectal cancer & Biomarkers for toxicities and response to neoadjuvant therapy \\
\hline NCT03608631/not yet recruiting & Pancreatic cancer & Treatment - mesenchymal stromal cells-derived EVs with KRAS G12D siRNA \\
\hline NCT01779583/unknown & Gastric cancer & Prognostic and predictive biomarkers \\
\hline NCT03874559/recruiting & Rectal cancer & Diagnostic biomarkers \\
\hline
\end{tabular}

Abbreviations: EVs- Extracellular vesicles; ncRNA-non-coding RNA; NSCLC-non-small cell lung cancer; PDL-1programmed cell death ligand 1; siRNA-silence interfering RNA.

All the abovementioned features of EVs render them as suitable candidates for targeted therapies, especially for cancer. However, there are some challenges in attempts for use in broad applications for cancer therapy, such as lack of standardized methods of isolation and purification of EVs, and challenges in identifying optimized methods for loading EVs with therapeutic compounds [217-219]. As of now, there are several studies on the use of engineered EVs loaded with different molecules/drugs for in vitro and/or in vivo experiments in cancer research, and these are summarized in Table 3. 
Table 3. Studies focused on investigating the effect of EVs-based therapy in in vivo and in vitro.

\begin{tabular}{|c|c|c|c|c|c|c|}
\hline Pathology & $\begin{array}{l}\text { EVs/Extracellular Vesicles } \\
\text { Derived From }\end{array}$ & Cargo & Method of Engineering & In Vitro/In Vivo & Effect & Reference \\
\hline \multirow{2}{*}{ Ovarian cancer } & \multirow{2}{*}{ Fibroblasts from normal omentum } & \multirow{2}{*}{ miR-199a-3p } & \multirow{2}{*}{ Electroporation } & $\begin{array}{l}\text { SKOV3ip1, OVCAR3, CaOV3 } \\
\text { and SKOV3-13 }\end{array}$ & $\begin{array}{l}\text { Inhibition of ovarian cancer cell proliferation, invasiveness, and } \\
\text { c-Met expression. }\end{array}$ & \multirow[t]{2}{*}{ [215] } \\
\hline & & & & BALB/c nude mice & Inhibition of ovarian cancer peritoneal dissemination. & \\
\hline Cancer & M1 macrophages & $\mathrm{aCD} 47$ and SIRP $\alpha$ & Polarization and conjugation & 4T1tumor-bearing BALB/c mice & enhanced the phagocytosis of macrophages & [220] \\
\hline Cancer & Bel7402 cell line & $\begin{array}{l}\text { Doxorubicin-loaded } \\
\text { PSiNPs (porous silicone } \\
\text { nanoparticles) }\end{array}$ & Incubation & $\begin{array}{l}\text { BALB/c mice and C57BL/6 mice } \\
\text { bearing H22 tumors }\end{array}$ & Enhanced tumor accumulation of doxorubicin & [221] \\
\hline Small cell lung cancer & BEAS-2B and NCI-H69 cell lines & sFlt-1 & $\begin{array}{l}\text { Cloning sFlt-1 into a lentivirus } \\
\text { and obtaining engineered cell } \\
\text { lines overexpressing sFlt-1 }\end{array}$ & $\begin{array}{l}\text { Nude mice with NCI-H69 } \\
\text { xenografts }\end{array}$ & Induction of tumor apoptosis and inhibition tumor cell proliferation. & [212] \\
\hline \multirow{2}{*}{ Glioma } & \multirow{2}{*}{ RAW264.7 cells } & \multirow{2}{*}{ Doxorubicin } & \multirow{2}{*}{ Incubation } & GL261 cells and RAW264.7 cells & Uptake of loaded EVs is higher in cancer cells than in normal cells & \multirow{2}{*}{ [222] } \\
\hline & & & & C57BL/6 mice & Increased blood circulation time & \\
\hline \multirow[b]{2}{*}{ Breast cancer } & \multirow[b]{2}{*}{ Artificial chimeric EVs (ACEs) } & \multirow[b]{2}{*}{ Doxorubicin } & \multirow{2}{*}{$\begin{array}{c}\text { Integration of RBCs and MCF-7 } \\
\text { cell membrane proteins into } \\
\text { synthetic } \\
\text { phospholipid bilayers. }\end{array}$} & MCF-7 cells & Inhibition of cellular growth & \multirow{2}{*}{ [223] } \\
\hline & & & & $\begin{array}{l}\text { BALB/c nude mice and } \\
\text { ICR mice }\end{array}$ & Doxorubicin accumulation in tumor improving anti-tumor efficacy & \\
\hline $\begin{array}{l}\text { Hepatocellular } \\
\text { carcinoma }\end{array}$ & Plasma of healthy blood donors & $\mathrm{miR}-31$ and $\mathrm{miR}-451$ & Electroporation & HepG2 cells & Increased cancer cell apoptosis. & [224] \\
\hline Breast cancer & MSC & Doxorubicin & Electroporation & BT-474 and MDA-MB231 cells & $\begin{array}{l}\text { Reduced cell viability, but with no significant differences between } \\
\text { free DOX and EVs encapsulate DOX }\end{array}$ & [225] \\
\hline Her2+ Breast Cancer & HEK $293 \mathrm{~T}$ cells & siRNA & $\begin{array}{c}\text { pLEX-LAMP-DARPin } \\
\text { lentiviral transduction in HEK } \\
\text { 293T cells } \\
\end{array}$ & SKBR3 cells & $\begin{array}{l}\text { Increased suppression of target gene (TPD52) compared to untreated } \\
\text { cells and negative control (unloaded EVs) }\end{array}$ & [226] \\
\hline Breast cancer & MSC & $\operatorname{miR}-379$ & lentiviral transduction of MSCs & BALB/c nude mice & $\begin{array}{c}\begin{array}{c}\text { Reduction in tumor size compared to the negative control (NTC } \\
\text { extracellular vesicles) }\end{array}\end{array}$ & [227] \\
\hline NSCLC & RAW 264.7 cells & Paclitaxel & $\begin{array}{l}\text { Sonication and incubation } \\
\text { (including vectorization of } \\
\text { EVs-AA-PEG-exoPTX) }\end{array}$ & $\begin{array}{l}\text { C57BL/6 mice with established } \\
\text { mCherry-3LL-M27 metastases }\end{array}$ & $\begin{array}{l}\text { Stronger suppression of metastases growth and greater survival time } \\
\text { as compared to Taxol, or non-vectorized exoPTX formulation }\end{array}$ & [228] \\
\hline \multirow[b]{2}{*}{ Pancreatic cancer } & \multirow{2}{*}{$\begin{array}{l}\text { Normal fibroblast-like } \\
\text { mesenchymal cells }\end{array}$} & \multirow{2}{*}{$\begin{array}{l}\text { siRNA or shRNA targeting } \\
\operatorname{Kras}^{\mathrm{G} 12 \mathrm{D}}\end{array}$} & \multirow[b]{2}{*}{ Electroporation } & Panc-1 cells & Enhanced apoptosis and decreased proliferation & \multirow[b]{2}{*}{ [229] } \\
\hline & & & & $\begin{array}{l}\mathrm{Nu} / \mathrm{nu} \text { mice with orthotopic } \\
\text { Panc-1 tumors }\end{array}$ & Controlled growth of tumors & \\
\hline \multirow{2}{*}{$\begin{array}{c}\text { Chronic myeloid } \\
\text { leukemia }\end{array}$} & \multirow{2}{*}{ HEK293T cells } & \multirow{2}{*}{ Imatinib (IL3 EVs) } & \multirow{2}{*}{ Incubation } & LAMA84 and K562R cells & Reduction in cell viability compared to empty imatinib loaded EVs & \multirow{2}{*}{ [230] } \\
\hline & & & & NOD/SCID mice & Reduction in tumor size & \\
\hline Melanoma & B16BL6 cells & CpG-DNA (SAV-LA EVs) & Incubation & $\begin{array}{l}\text { C57BL/6J mice and BALB/c } \\
\text { nu/nu mice }\end{array}$ & Inhibition of tumor growth. & [231] \\
\hline \multirow[b]{2}{*}{ Breast cancer } & \multirow{2}{*}{$\begin{array}{l}\text { immature mouse dendritic cell line } \\
\text { (imDC) }\end{array}$} & \multirow{2}{*}{$\begin{array}{l}\text { Doxorubicin } \\
\text { (iRGD-positive EVs) }\end{array}$} & \multirow[b]{2}{*}{ Electroporation } & MDA-MB-231 & Inhibition of cell proliferation & \multirow[b]{2}{*}{ [232] } \\
\hline & & & & $\begin{array}{l}\text { MDA-MB-231 tumor-bearing } \\
\text { BALB/c nude mice }\end{array}$ & $\begin{array}{c}\text { Inhibition of tumor growth due to effective accumulation of Dox at } \\
\text { tumor sites }\end{array}$ & \\
\hline Breast cancer & HEK293 & let-7 (GE11-positive EVs) & lipofection & RAG2-/-mice & Suppression of tumor growth & [233] \\
\hline
\end{tabular}

Abbreviations: EVs, extracellular vesicles; MSC, mesenchymal stem cells; NSCLC, non-small cell lung cancer; siRNA, small interfering RNA; shRNA, short hairpin RNA; DC; dendritic cells. 


\section{Conclusions}

EVs represent particles released from both normal and malignant cells that have important biological roles in ensuring cell-to-cell communication, not only for neighboring cells but also for distant cells. EVs are classified as EVs, multivesicular bodies and apoptotic bodies, of different sizes, origin, and protein and lipid compositions. These EVs play critical roles in pathological states of cells, regulating all hallmarks of cancer cells and resistance to drug treatments, thus highlighting the potential of these entities in the management of cancer. EV capabilities in carrying different active biomolecules, such as different RNA species, DNA, and proteins for targeting recipient cells without triggering immune responses, have rendered them as valuable biological entities for use as therapeutic agents that can overcome the shortcomings of complex diseases, such as cancer.

Author Contributions: Conceptualization, A.J. and C.P.-B.; methodology, W.C.C.; validation, O.S. and C.D.Ş.; formal analysis, C.D.S..; investigation, A.J., C.P-B., W.C.C., and I.B.-N.; writing-original draft preparation, A.J., C.P-B., O.S., C.D.Ş., W.C.C., and I.B.-N.; writing-review and editing, W.C.C., S.S.K., and I.B.-N.; visualization, A.J., C.P.-B., O.S., C.D.Ş., W.C.C., and I.B.-N.; supervision, I.B.-N.; project administration, I.B.-N.; funding acquisition, I.B.-N. All authors have read and agreed to the published version of the manuscript.

Funding: This research was funded by H2020-MSCA-RISE-2018 No. 824036/2019`Excellence in research and development of non-coding RNA DIAGnostics in Oncology' (RNADIAGON), project PNCDI III 2015-2020 titled "Increasing the performance of scientific research and technology transfer in translational medicine through the formation of a new generation of young researchers"-ECHITAS, No. 29PFE/18.10.2018 and Competitiveness Operational Program, 2014-2020, titled "Clinical and economic impact of personalized targeted anti-microRNA therapies in reconverting lung cancer chemoresistance"-CANTEMIR, No. 35/01.09.2016, MySMIS 103375.

Conflicts of Interest: The authors declare no conflict of interest.

\section{References}

1. Maia, J.; Caja, S.; Strano Moraes, M.C.; Couto, N.; Costa-Silva, B. Exosome-Based Cell-Cell Communication in the Tumor Microenvironment. Front. Cell Dev. Biol. 2018, 6, 18. [CrossRef] [PubMed]

2. McCrea, P.D.; Gu, D.; Balda, M.S. Junctional Music that the Nucleus Hears: Cell-Cell Contact Signaling and the Modulation of Gene Activity. Cold Spring Harb. Perspect. Biol. 2009, 1, a002923. [CrossRef] [PubMed]

3. Brücher, B.L.D.M.; Jamall, I.S. Cell-Cell Communication in the Tumor Microenvironment, Carcinogenesis, and Anticancer Treatment. Cell Physiol. Biochem. 2014, 34, 213-243. [CrossRef] [PubMed]

4. Lee, Y.; EL Andaloussi, S.; Wood, M.J.A. Exosomes and microvesicles: Extracellular vesicles for genetic information transfer and gene therapy. Hum. Mol. Genet. 2012, 21, R125-R134. [CrossRef] [PubMed]

5. Harding, C.; Heuser, J.; Stahl, P. Endocytosis and intracellular processing of transferrin and colloidal gold-transferrin in rat reticulocytes: Demonstration of a pathway for receptor shedding. Eur. J. Cell Biol. 1984, 35, 256-263.

6. Lai, R.C.; Chen, T.S.; Lim, S.K. Mesenchymal stem cell exosome: A novel stem cell-based therapy for cardiovascular disease. Regen. Med. 2011, 6, 481-492. [CrossRef]

7. Guescini, M.; Genedani, S.; Stocchi, V.; Agnati, L.F. Astrocytes and Glioblastoma cells release exosomes carrying mtDNA. J. Neural Transm. 2010, 117, 1-4. [CrossRef]

8. Ratajczak, J.; Miekus, K.; Kucia, M.; Zhang, J.; Reca, R.; Dvorak, P.; Ratajczak, M.Z. Embryonic stem cell-derived microvesicles reprogram hematopoietic progenitors: Evidence for horizontal transfer of mRNA and protein delivery. Leukemia 2006, 20, 847-856. [CrossRef]

9. Raposo, G.; Nijman, H.W.; Stoorvogel, W.; Liejendekker, R.; Harding, C.V.; Melief, C.J.; Geuze, H.J. B lymphocytes secrete antigen-presenting vesicles. J. Exp. Med. 1996, 183, 1161-1172. [CrossRef]

10. Gatti, S.; Bruno, S.; Deregibus, M.C.; Sordi, A.; Cantaluppi, V.; Tetta, C.; Camussi, G. Microvesicles derived from human adult mesenchymal stem cells protect against ischaemia-reperfusion-induced acute and chronic kidney injury. Nephrol. Dial. Transplant. 2011, 26, 1474-1483. [CrossRef]

11. Olejarz, W.; Dominiak, A.; Żołnierzak, A.; Kubiak-Tomaszewska, G.; Lorenc, T. Tumor-Derived Exosomes in Immunosuppression and Immunotherapy. J. Immunol. Res. 2020, 2020, 6272498. [CrossRef] [PubMed]

12. Besse, B.; Charrier, M.; Lapierre, V.; Dansin, E.; Lantz, O.; Planchard, D.; Le Chevalier, T.; Livartoski, A.; Barlesi, F.; Laplanche, A.; et al. Dendritic cell-derived exosomes as maintenance immunotherapy after first line chemotherapy in NSCLC. OncoImmunology 2016, 5, e1071008. [CrossRef] [PubMed] 
13. Rak, J.; Guha, A. Extracellular vesicles_Vehicles that spread cancer genes. Bioessays 2012, 34, $489-497$. [CrossRef] [PubMed]

14. Bellingham, S.A.; Guo, B.B.; Coleman, B.M.; Hill, A.F. Exosomes: Vehicles for the Transfer of Toxic Proteins Associated with Neurodegenerative Diseases? Front. Physiol. 2012, 3, 124. [CrossRef] [PubMed]

15. Emmanouilidou, E.; Melachroinou, K.; Roumeliotis, T.; Garbis, S.D.; Ntzouni, M.; Margaritis, L.H.; Stefanis, L.; Vekrellis, K. Cell-Produced -Synuclein Is Secreted in a Calcium-Dependent Manner by Exosomes and Impacts Neuronal Survival. J. Neurosci. 2010, 30, 6838-6851. [CrossRef] [PubMed]

16. Tai, Y.-L.; Chu, P.-Y.; Lee, B.-H.; Chen, K.-C.; Yang, C.-Y.; Kuo, W.-H.; Shen, T.-L. Basics and applications of tumor-derived extracellular vesicles. J. Biomed. Sci. 2019, 26, 35. [CrossRef]

17. EL Andaloussi, S.; Mäger, I.; Breakefield, X.O.; Wood, M.J.A. Extracellular vesicles: Biology and emerging therapeutic opportunities. Nat. Rev. Drug Discov. 2013, 12, 347-357. [CrossRef]

18. Jurj, A.; Pasca, S.; Teodorescu, P.; Tomuleasa, C.; Berindan-Neagoe, I. Basic knowledge on BCR-ABL1-positive extracellular vesicles. Biomark. Med. 2020, 14, 451-458. [CrossRef]

19. Gebara, N.; Rossi, A.; Skovronova, R.; Aziz, J.M.; Asthana, A.; Bussolati, B. Extracellular Vesicles, Apoptotic Bodies and Mitochondria: Stem Cell Bioproducts for Organ Regeneration. Curr. Transpl. Rep. 2020, 7 , 105-113. [CrossRef]

20. Kakarla, R.; Hur, J.; Kim, Y.J.; Kim, J.; Chwae, Y.-J. Apoptotic cell-derived exosomes: Messages from dying cells. Exp. Mol. Med. 2020, 52,1-6. [CrossRef]

21. Gardai, S.J.; McPhillips, K.A.; Frasch, S.C.; Janssen, W.J.; Starefeldt, A.; Murphy-Ullrich, J.E.; Bratton, D.L.; Oldenborg, P.-A.; Michalak, M.; Henson, P.M. Cell-Surface Calreticulin Initiates Clearance of Viable or Apoptotic Cells through trans-Activation of LRP on the Phagocyte. Cell 2005, 123, 321-334. [CrossRef] [PubMed]

22. Lunavat, T.R.; Cheng, L.; Kim, D.-K.; Bhadury, J.; Jang, S.C.; Lässer, C.; Sharples, R.A.; López, M.D.; Nilsson, J.; Gho, Y.S.; et al. Small RNA deep sequencing discriminates subsets of extracellular vesicles released by melanoma cells-Evidence of unique microRNA cargos. RNA Biol. 2015, 12, 810-823. [CrossRef] [PubMed]

23. Caruso, S.; Poon, I.K.H. Apoptotic Cell-Derived Extracellular Vesicles: More Than Just Debris. Front. Immunol. 2018, 9, 1486. [CrossRef]

24. Akers, J.C.; Gonda, D.; Kim, R.; Carter, B.S.; Chen, C.C. Biogenesis of extracellular vesicles (EV): Exosomes, microvesicles, retrovirus-like vesicles, and apoptotic bodies. J. Neurooncol. 2013, 113, 1-11. [CrossRef]

25. Jurj, A.; Zanoaga, O.; Braicu, C.; Lazar, V.; Tomuleasa, C.; Irimie, A.; Berindan-Neagoe, I. A Comprehensive Picture of Extracellular Vesicles and Their Contents. Molecular Transfer to Cancer Cells. Cancers 2020, 12, 298. [CrossRef] [PubMed]

26. Borges, F.T.; Reis, L.A.; Schor, N. Extracellular vesicles: Structure, function, and potential clinical uses in renal diseases. Braz. J. Med. Biol. Res. 2013, 46, 824-830. [CrossRef]

27. Ailawadi, S.; Wang, X.; Gu, H.; Fan, G.-C. Pathologic function and therapeutic potential of exosomes in cardiovascular disease. Biochim. Biophys. Acta (BBA) Mol. Basis Dis. 2015, 1852, 1-11. [CrossRef]

28. Kajimoto, T.; Okada, T.; Miya, S.; Zhang, L.; Nakamura, S. Ongoing activation of sphingosine 1-phosphate receptors mediates maturation of exosomal multivesicular endosomes. Nat. Commun. 2013, 4, 2712. [CrossRef]

29. Kowal, J.; Tkach, M.; Théry, C. Biogenesis and secretion of exosomes. Curr. Opin. Cell Biol. 2014, 29, 116-125. [CrossRef]

30. Ekström, E.J.; Bergenfelz, C.; von Bülow, V.; Serifler, F.; Carlemalm, E.; Jönsson, G.; Andersson, T.; Leandersson, K. WNT5A induces release of exosomes containing pro-angiogenic and immunosuppressive factors from malignant melanoma cells. Mol. Cancer 2014, 13, 88. [CrossRef]

31. Chuo, S.T.-Y.; Chien, J.C.-Y.; Lai, C.P.-K. Imaging extracellular vesicles: Current and emerging methods. J. Biomed. Sci. 2018, 25, 91. [CrossRef] [PubMed]

32. Willms, E.; Cabañas, C.; Mäger, I.; Wood, M.J.A.; Vader, P. Extracellular Vesicle Heterogeneity: Subpopulations, Isolation Techniques, and Diverse Functions in Cancer Progression. Front. Immunol. 2018, 9, 738. [CrossRef]

33. Doyle, L.; Wang, M. Overview of Extracellular Vesicles, Their Origin, Composition, Purpose, and Methods for Exosome Isolation and Analysis. Cells 2019, 8, 727. [CrossRef] [PubMed]

34. Xie, C.; Ji, N.; Tang, Z.; Li, J.; Chen, Q. The role of extracellular vesicles from different origin in the microenvironment of head and neck cancers. Mol. Cancer 2019, 18, 83. [CrossRef] [PubMed] 
35. Zhang, Y.; Liu, Y.; Liu, H.; Tang, W.H. Exosomes: Biogenesis, biologic function and clinical potential. Cell Biosci. 2019, 9, 19. [CrossRef] [PubMed]

36. Zaborowski, M.P.; Balaj, L.; Breakefield, X.O.; Lai, C.P. Extracellular Vesicles: Composition, Biological Relevance, and Methods of Study. BioScience 2015, 65, 783-797. [CrossRef]

37. Simeone, P.; Bologna, G.; Lanuti, P.; Pierdomenico, L.; Guagnano, M.T.; Pieragostino, D.; Del Boccio, P.; Vergara, D.; Marchisio, M.; Miscia, S.; et al. Extracellular Vesicles as Signaling Mediators and Disease Biomarkers across Biological Barriers. Int. J. Mol. Sci. 2020, 21, 2514. [CrossRef]

38. Catalano, M.; O’Driscoll, L. Inhibiting extracellular vesicles formation and release: A review of EV inhibitors. J. Extracell. Vesicles 2020, 9, 1703244. [CrossRef]

39. Joshi, B.S.; de Beer, M.A.; Giepmans, B.N.G.; Zuhorn, I.S. Endocytosis of Extracellular Vesicles and Release of Their Cargo from Endosomes. ACS Nano 2020, 14, 4444-4455. [CrossRef]

40. Théry, C.; Ostrowski, M.; Segura, E. Membrane vesicles as conveyors of immune responses. Nat. Rev. Immunol. 2009, 9, 581-593. [CrossRef]

41. Villarroya-Beltri, C.; Baixauli, F.; Gutiérrez-Vázquez, C.; Sánchez-Madrid, F.; Mittelbrunn, M. Sorting it out: Regulation of exosome loading. Semin. Cancer Biol. 2014, 28, 3-13. [CrossRef]

42. Thakur, B.K.; Zhang, H.; Becker, A.; Matei, I.; Huang, Y.; Costa-Silva, B.; Zheng, Y.; Hoshino, A.; Brazier, H.; Xiang, J.; et al. Double-stranded DNA in exosomes: A novel biomarker in cancer detection. Cell Res. 2014, 24, 766-769. [CrossRef] [PubMed]

43. Fischer, S.; Cornils, K.; Speiseder, T.; Badbaran, A.; Reimer, R.; Indenbirken, D.; Grundhoff, A.; Brunswig-Spickenheier, B.; Alawi, M.; Lange, C. Indication of Horizontal DNA Gene Transfer by Extracellular Vesicles. PLoS ONE 2016, 11, e0163665. [CrossRef] [PubMed]

44. Shelke, G.; Jang, S.C.; Yin, Y.; Lässer, C.; Lötvall, J. Human mast cells release extracellular vesicle-associated DNA. Matters 2016, 2, e201602000034. [CrossRef]

45. Kawamura, Y.; Yamamoto, Y.; Sato, T.-A.; Ochiya, T. Extracellular vesicles as trans-genomic agents: Emerging roles in disease and evolution. Cancer Sci. 2017, 108, 824-830. [CrossRef]

46. Record, M.; Subra, C.; Silvente-Poirot, S.; Poirot, M. Exosomes as intercellular signalosomes and pharmacological effectors. Biochem. Pharmacol. 2011, 81, 1171-1182. [CrossRef] [PubMed]

47. Choi, D.-S.; Kim, D.-K.; Kim, Y.-K.; Gho, Y.S. Proteomics, transcriptomics and lipidomics of exosomes and ectosomes. Proteomics 2013, 13, 1554-1571. [CrossRef]

48. Yáñez-Mó, M.; Siljander, P.R.-M.; Andreu, Z.; Bedina Zavec, A.; Borràs, F.E.; Buzas, E.I.; Buzas, K.; Casal, E.; Cappello, F.; Carvalho, J.; et al. Biological properties of extracellular vesicles and their physiological functions. J. Extracell. Vesicles 2015, 4, 27066. [CrossRef] [PubMed]

49. Chen, T.; Guo, J.; Yang, M.; Zhu, X.; Cao, X. Chemokine-Containing Exosomes Are Released from Heat-Stressed Tumor Cells via Lipid Raft-Dependent Pathway and Act as Efficient Tumor Vaccine. J. Immunol. 2011, 186, 2219-2228. [CrossRef]

50. Li, I.; Nabet, B.Y. Exosomes in the tumor microenvironment as mediators of cancer therapy resistance. Mol. Cancer 2019, 18, 32. [CrossRef]

51. Cvjetkovic, A.; Lötvall, J.; Lässer, C. The influence of rotor type and centrifugation time on the yield and purity of extracellular vesicles. J. Extracell. Vesicles 2014, 3, 23111. [CrossRef] [PubMed]

52. Konoshenko, M.Y.; Lekchnov, E.A.; Vlassov, A.V.; Laktionov, P.P. Isolation of Extracellular Vesicles: General Methodologies and Latest Trends. Biomed. Res. Int. 2018, 2018, 8545347. [CrossRef] [PubMed]

53. Böing, A.N.; van der Pol, E.; Grootemaat, A.E.; Coumans, F.A.W.; Sturk, A.; Nieuwland, R. Single-step isolation of extracellular vesicles by size-exclusion chromatography. J. Extracell. Vesicles 2014, 3, 23430. [CrossRef] [PubMed]

54. Yamamoto, K.R.; Alberts, B.M.; Benzinger, R.; Lawhorne, L.; Treiber, G. Rapid bacteriophage sedimentation in the presence of polyethylene glycol and its application to large-scale virus purification. Virology 1970, 40, 734-744. [CrossRef]

55. Li, P.; Kaslan, M.; Lee, S.H.; Yao, J.; Gao, Z. Progress in Exosome Isolation Techniques. Theranostics 2017, 7, 789-804. [CrossRef]

56. Liu, F.; Vermesh, O.; Mani, V.; Ge, T.J.; Madsen, S.J.; Sabour, A.; Hsu, E.-C.; Gowrishankar, G.; Kanada, M.; Jokerst, J.V.; et al. The Exosome Total Isolation Chip. ACS Nano 2017, 11, 10712-10723. [CrossRef] 
57. Wu, M.; Ouyang, Y.; Wang, Z.; Zhang, R.; Huang, P.-H.; Chen, C.; Li, H.; Li, P.; Quinn, D.; Dao, M.; et al. Isolation of exosomes from whole blood by integrating acoustics and microfluidics. Proc. Natl. Acad. Sci. USA 2017, 114, 10584-10589. [CrossRef]

58. Gallart-Palau, X.; Serra, A.; Wong, A.S.W.; Sandin, S.; Lai, M.K.P.; Chen, C.P.; Kon, O.L.; Sze, S.K. Extracellular vesicles are rapidly purified from human plasma by PRotein Organic Solvent PRecipitation (PROSPR). Sci. Rep. 2015, 5, 14664. [CrossRef]

59. Heath, N.; Grant, L.; De Oliveira, T.M.; Rowlinson, R.; Osteikoetxea, X.; Dekker, N.; Overman, R. Rapid isolation and enrichment of extracellular vesicle preparations using anion exchange chromatography. Sci. Rep. 2018, 8, 5730. [CrossRef]

60. Merchant, M.L.; Powell, D.W.; Wilkey, D.W.; Cummins, T.D.; Deegens, J.K.; Rood, I.M.; McAfee, K.J.; Fleischer, C.; Klein, E.; Klein, J.B. Microfiltration isolation of human urinary exosomes for characterization by MS. Proteom. Clin. Appl. 2010, 4, 84-96. [CrossRef]

61. Usman, W.M.; Pham, T.C.; Kwok, Y.Y.; Vu, L.T.; Ma, V.; Peng, B.; Chan, Y.S.; Wei, L.; Chin, S.M.; Azad, A.; et al. Efficient RNA drug delivery using red blood cell extracellular vesicles. Nat. Commun. 2018, 9, 2359. [CrossRef]

62. Gercel-Taylor, C.; Atay, S.; Tullis, R.H.; Kesimer, M.; Taylor, D.D. Nanoparticle analysis of circulating cell-derived vesicles in ovarian cancer patients. Anal. Biochem. 2012, 428, 44-53. [CrossRef] [PubMed]

63. Vestad, B.; Llorente, A.; Neurauter, A.; Phuyal, S.; Kierulf, B.; Kierulf, P.; Skotland, T.; Sandvig, K.; Haug, K.B.F.; Øvstebø, R. Size and concentration analyses of extracellular vesicles by nanoparticle tracking analysis: A variation study. J. Extracell. Vesicles 2017, 6, 1344087. [CrossRef] [PubMed]

64. Headland, S.E.; Jones, H.R.; D'Sa, A.S.V.; Perretti, M.; Norling, L.V. Cutting-edge analysis of extracellular microparticles using ImageStream $(X)$ imaging flow cytometry. Sci. Rep. 2014, 4, 5237. [CrossRef] [PubMed]

65. Linares, R.; Tan, S.; Gounou, C.; Brisson, A.R. Imaging and Quantification of Extracellular Vesicles by Transmission Electron Microscopy. Methods Mol. Biol. 2017, 1545, 43-54. [CrossRef]

66. Sprague, D.L.; Elzey, B.D.; Crist, S.A.; Waldschmidt, T.J.; Jensen, R.J.; Ratliff, T.L. Platelet-mediated modulation of adaptive immunity: Unique delivery of CD154 signal by platelet-derived membrane vesicles. Blood 2008, 111, 5028-5036. [CrossRef]

67. Baj-Krzyworzeka, M.; Mytar, B.; Szatanek, R.; Surmiak, M.; Węglarczyk, K.; Baran, J.; Siedlar, M. Colorectal cancer-derived microvesicles modulate differentiation of human monocytes to macrophages. J. Transl. Med. 2016, 14, 36. [CrossRef]

68. Simhadri, V.R.; Reiners, K.S.; Hansen, H.P.; Topolar, D.; Simhadri, V.L.; Nohroudi, K.; Kufer, T.A.; Engert, A.; Pogge von Strandmann, E. Dendritic Cells Release HLA-B-Associated Transcript-3 Positive Exosomes to Regulate Natural Killer Function. PLoS ONE 2008, 3, e3377. [CrossRef]

69. Clayton, A.; Mitchell, J.P.; Court, J.; Linnane, S.; Mason, M.D.; Tabi, Z. Human Tumor-Derived Exosomes Down-Modulate NKG2D Expression. J. Immunol. 2008, 180, 7249-7258. [CrossRef]

70. Eken, C.; Gasser, O.; Zenhaeusern, G.; Oehri, I.; Hess, C.; Schifferli, J.A. Polymorphonuclear Neutrophil-Derived Ectosomes Interfere with the Maturation of Monocyte-Derived Dendritic Cells. J. Immunol. 2008, 180, 817-824. [CrossRef]

71. Yu, S.; Liu, C.; Su, K.; Wang, J.; Liu, Y.; Zhang, L.; Li, C.; Cong, Y.; Kimberly, R.; Grizzle, W.E.; et al. Tumor Exosomes Inhibit Differentiation of Bone Marrow Dendritic Cells. J. Immunol. 2007, 178, 6867-6875. [CrossRef] [PubMed]

72. Camussi, G.; Deregibus, M.-C.; Bruno, S.; Grange, C.; Fonsato, V.; Tetta, C. Exosome/microvesicle-mediated epigenetic reprogramming of cells. Am. J. Cancer Res. 2011, 1, 98-110.

73. Jang, Y.-Y.; Collector, M.I.; Baylin, S.B.; Diehl, A.M.; Sharkis, S.J. Hematopoietic stem cells convert into liver cells within days without fusion. Nat. Cell Biol. 2004, 6, 532-539. [CrossRef]

74. Quesenberry, P.J.; Aliotta, J.M. Cellular phenotype switching and microvesicles. Adv. Drug Deliv. Rev. 2010, 62, 1141-1148. [CrossRef] [PubMed]

75. Peinado, H.; Alečković, M.; Lavotshkin, S.; Matei, I.; Costa-Silva, B.; Moreno-Bueno, G.; Hergueta-Redondo, M.; Williams, C.; García-Santos, G.; Ghajar, C.; et al. Melanoma exosomes educate bone marrow progenitor cells toward a pro-metastatic phenotype through MET. Nat. Med. 2012, 18, 883-891. [CrossRef] [PubMed] 
76. Skog, J.; Würdinger, T.; van Rijn, S.; Meijer, D.H.; Gainche, L.; Curry, W.T.; Carter, B.S.; Krichevsky, A.M.; Breakefield, X.O. Glioblastoma microvesicles transport RNA and proteins that promote tumour growth and provide diagnostic biomarkers. Nat. Cell Biol. 2008, 10, 1470-1476. [CrossRef]

77. Al-Nedawi, K.; Meehan, B.; Kerbel, R.S.; Allison, A.C.; Rak, J. Endothelial expression of autocrine VEGF upon the uptake of tumor-derived microvesicles containing oncogenic EGFR. Proc. Natl. Acad. Sci. USA 2009, 106, 3794-3799. [CrossRef]

78. Hu, C.; Meiners, S.; Lukas, C.; Stathopoulos, G.T.; Chen, J. Role of exosomal microRNAs in lung cancer biology and clinical applications. Cell Prolif. 2020, 53. [CrossRef]

79. Kumar, A.; Deep, G. Exosomes in hypoxia-induced remodeling of the tumor microenvironment. Cancer Lett. 2020, 488, 1-8. [CrossRef]

80. Lee, J.-K.; Park, S.-R.; Jung, B.-K.; Jeon, Y.-K.; Lee, Y.-S.; Kim, M.-K.; Kim, Y.-G.; Jang, J.-Y.; Kim, C.-W. Exosomes Derived from Mesenchymal Stem Cells Suppress Angiogenesis by Down-Regulating VEGF Expression in Breast Cancer Cells. PLoS ONE 2013, 8, e84256. [CrossRef]

81. Umezu, T.; Ohyashiki, K.; Kuroda, M.; Ohyashiki, J.H. Leukemia cell to endothelial cell communication via exosomal miRNAs. Oncogene 2013, 32, 2747-2755. [CrossRef] [PubMed]

82. Kalinina, N.; Klink, G.; Glukhanyuk, E.; Lopatina, T.; Efimenko, A.; Akopyan, Z.; Tkachuk, V. miR-92a regulates angiogenic activity of adipose-derived mesenchymal stromal cells. Exp. Cell Res. 2015, 339, 61-66. [CrossRef]

83. Liu, Y.; Luo, F.; Wang, B.; Li, H.; Xu, Y.; Liu, X.; Shi, L.; Lu, X.; Xu, W.; Lu, L.; et al. STAT3-regulated exosomal miR-21 promotes angiogenesis and is involved in neoplastic processes of transformed human bronchial epithelial cells. Cancer Lett. 2016, 370, 125-135. [CrossRef] [PubMed]

84. Mao, G.; Liu, Y.; Fang, X.; Liu, Y.; Fang, L.; Lin, L.; Liu, X.; Wang, N. Tumor-derived microRNA-494 promotes angiogenesis in non-small cell lung cancer. Angiogenesis 2015, 18, 373-382. [CrossRef]

85. Grange, C.; Tapparo, M.; Collino, F.; Vitillo, L.; Damasco, C.; Deregibus, M.C.; Tetta, C.; Bussolati, B.; Camussi, G. Microvesicles Released from Human Renal Cancer Stem Cells Stimulate Angiogenesis and Formation of Lung Premetastatic Niche. Cancer Res. 2011, 71, 5346-5356. [CrossRef] [PubMed]

86. Sidhu, S.S.; Mengistab, A.T.; Tauscher, A.N.; LaVail, J.; Basbaum, C. The microvesicle as a vehicle for EMMPRIN in tumor-stromal interactions. Oncogene 2004, 23, 956-963. [CrossRef] [PubMed]

87. Le, M.T.N.; Hamar, P.; Guo, C.; Basar, E.; Perdigão-Henriques, R.; Balaj, L.; Lieberman, J. miR-200-containing extracellular vesicles promote breast cancer cell metastasis. J. Clin. Invest. 2014, 124, 5109-5128. [CrossRef] [PubMed]

88. Liao, J.; Liu, R.; Shi, Y.-J.; Yin, L.-H.; Pu, Y.-P. Exosome-shuttling microRNA-21 promotes cell migration and invasion-targeting PDCD4 in esophageal cancer. Int. J. Oncol. 2016, 48, 2567-2579. [CrossRef]

89. Zhou, W.; Fong, M.Y.; Min, Y.; Somlo, G.; Liu, L.; Palomares, M.R.; Yu, Y.; Chow, A.; O'Connor, S.T.F.; Chin, A.R.; et al. Cancer-secreted miR-105 destroys vascular endothelial barriers to promote metastasis. Cancer Cell 2014, 25, 501-515. [CrossRef]

90. Wang, L.; He, J.; Hu, H.; Tu, L.; Sun, Z.; Liu, Y.; Luo, F. Lung CSC-derived exosomal miR-210-3p contributes to a pro-metastatic phenotype in lung cancer by targeting FGFRL1. J. Cell Mol. Med. 2020, 24, 6324-6339. [CrossRef]

91. Higginbotham, J.N.; Demory Beckler, M.; Gephart, J.D.; Franklin, J.L.; Bogatcheva, G.; Kremers, G.-J.; Piston, D.W.; Ayers, G.D.; McConnell, R.E.; Tyska, M.J.; et al. Amphiregulin Exosomes Increase Cancer Cell Invasion. Curr. Biol. 2011, 21, 779-786. [CrossRef]

92. Al-Nedawi, K.; Meehan, B.; Micallef, J.; Lhotak, V.; May, L.; Guha, A.; Rak, J. Intercellular transfer of the oncogenic receptor EGFRvIII by microvesicles derived from tumour cells. Nat. Cell Biol. 2008, 10, 619-624. [CrossRef]

93. Fong, M.Y.; Zhou, W.; Liu, L.; Alontaga, A.Y.; Chandra, M.; Ashby, J.; Chow, A.; O'Connor, S.T.F.; Li, S.; Chin, A.R.; et al. Breast-cancer-secreted miR-122 reprograms glucose metabolism in premetastatic niche to promote metastasis. Nat. Cell Biol. 2015, 17, 183-194. [CrossRef] [PubMed]

94. Garnier, D.; Magnus, N.; Meehan, B.; Kislinger, T.; Rak, J. Qualitative changes in the proteome of extracellular vesicles accompanying cancer cell transition to mesenchymal state. Exp. Cell Res. 2013, 319, 2747-2757. [CrossRef] [PubMed] 
95. Tauro, B.J.; Mathias, R.A.; Greening, D.W.; Gopal, S.K.; Ji, H.; Kapp, E.A.; Coleman, B.M.; Hill, A.F.; Kusebauch, U.; Hallows, J.L.; et al. Oncogenic H-Ras Reprograms Madin-Darby Canine Kidney (MDCK) Cell-derived Exosomal Proteins Following Epithelial-Mesenchymal Transition. Mol. Cell Proteom. 2013, 12, 2148-2159. [CrossRef]

96. Aga, M.; Bentz, G.L.; Raffa, S.; Torrisi, M.R.; Kondo, S.; Wakisaka, N.; Yoshizaki, T.; Pagano, J.S.; Shackelford, J. Exosomal HIF1 $\alpha$ supports invasive potential of nasopharyngeal carcinoma-associated LMP1-positive exosomes. Oncogene 2014, 33, 4613-4622. [CrossRef] [PubMed]

97. Cai, Z.; Yang, F.; Yu, L.; Yu, Z.; Jiang, L.; Wang, Q.; Yang, Y.; Wang, L.; Cao, X.; Wang, J. Activated T Cell Exosomes Promote Tumor Invasion via Fas Signaling Pathway. J. Immunol. 2012, 188, 5954-5961. [CrossRef]

98. Gao, F.; Zhao, Z.-L.; Zhao, W.-T.; Fan, Q.-R.; Wang, S.-C.; Li, J.; Zhang, Y.-Q.; Shi, J.-W.; Lin, X.-L.; Yang, S.; et al. miR-9 modulates the expression of interferon-regulated genes and MHC class I molecules in human nasopharyngeal carcinoma cells. Biochem. Biophys. Res. Commun. 2013, 431, 610-616. [CrossRef]

99. Fabbri, M.; Paone, A.; Calore, F.; Galli, R.; Gaudio, E.; Santhanam, R.; Lovat, F.; Fadda, P.; Mao, C.; Nuovo, G.J.; et al. MicroRNAs bind to Toll-like receptors to induce prometastatic inflammatory response. Proc. Natl. Acad. Sci. USA 2012, 109, E2110-E2116. [CrossRef]

100. Ma, X.; Chen, Z.; Hua, D.; He, D.; Wang, L.; Zhang, P.; Wang, J.; Cai, Y.; Gao, C.; Zhang, X.; et al. Essential role for TrpC5-containing extracellular vesicles in breast cancer with chemotherapeutic resistance. Proc. Natl. Acad. Sci. USA 2014, 111, 6389-6394. [CrossRef]

101. Klibi, J.; Niki, T.; Riedel, A.; Pioche-Durieu, C.; Souquere, S.; Rubinstein, E.; Le Moulec, S.; Guigay, J.; Hirashima, M.; Guemira, F.; et al. Blood diffusion and Th1-suppressive effects of galectin-9-containing exosomes released by Epstein-Barr virus-infected nasopharyngeal carcinoma cells. Blood 2009, 113, 1957-1966. [CrossRef]

102. Yang, M.; Chen, J.; Su, F.; Yu, B.; Su, F.; Lin, L.; Liu, Y.; Huang, J.-D.; Song, E. Microvesicles secreted by macrophages shuttle invasion-potentiating microRNAs into breast cancer cells. Mol. Cancer 2011, 10, 117. [CrossRef] [PubMed]

103. Zhou, M.; Chen, J.; Zhou, L.; Chen, W.; Ding, G.; Cao, L. Pancreatic cancer derived exosomes regulate the expression of TLR4 in dendritic cells via miR-203. Cell. Immunol. 2014, 292, 65-69. [CrossRef] [PubMed]

104. Berchem, G.; Noman, M.Z.; Bosseler, M.; Paggetti, J.; Baconnais, S.; Le cam, E.; Nanbakhsh, A.; Moussay, E.; Mami-Chouaib, F.; Janji, B.; et al. Hypoxic tumor-derived microvesicles negatively regulate NK cell function by a mechanism involving TGF- $\beta$ and miR23a transfer. OncoImmunology 2016, 5, e1062968. [CrossRef]

105. Huber, V.; Fais, S.; Iero, M.; Lugini, L.; Canese, P.; Squarcina, P.; Zaccheddu, A.; Colone, M.; Arancia, G.; Gentile, M.; et al. Human Colorectal Cancer Cells Induce T-Cell Death Through Release of Proapoptotic Microvesicles: Role in Immune Escape. Gastroenterology 2005, 128, 1796-1804. [CrossRef] [PubMed]

106. Clayton, A.; Mitchell, J.P.; Court, J.; Mason, M.D.; Tabi, Z. Human Tumor-Derived Exosomes Selectively Impair Lymphocyte Responses to Interleukin-2. Cancer Res. 2007, 67, 7458-7466. [CrossRef] [PubMed]

107. Ashiru, O.; Boutet, P.; Fernandez-Messina, L.; Aguera-Gonzalez, S.; Skepper, J.N.; Vales-Gomez, M.; Reyburn, H.T. Natural Killer Cell Cytotoxicity Is Suppressed by Exposure to the Human NKG2D Ligand MICA*008 That Is Shed by Tumor Cells in Exosomes. Cancer Res. 2010, 70, 481-489. [CrossRef]

108. Condamine, T.; Ramachandran, I.; Youn, J.-I.; Gabrilovich, D.I. Regulation of Tumor Metastasis by Myeloid-Derived Suppressor Cells. Annu. Rev. Med. 2015, 66, 97-110. [CrossRef] [PubMed]

109. Xiang, X.; Poliakov, A.; Liu, C.; Liu, Y.; Deng, Z.; Wang, J.; Cheng, Z.; Shah, S.V.; Wang, G.-J.; Zhang, L.; et al. Induction of myeloid-derived suppressor cells by tumor exosomes. Int. J. Cancer 2009, 124, 2621-2633. [CrossRef]

110. Khan, S.; Jutzy, J.M.S.; Aspe, J.R.; McGregor, D.W.; Neidigh, J.W.; Wall, N.R. Survivin is released from cancer cells via exosomes. Apoptosis 2011, 16,1-12. [CrossRef]

111. Cappellesso, R.; Tinazzi, A.; Giurici, T.; Simonato, F.; Guzzardo, V.; Ventura, L.; Crescenzi, M.; Chiarelli, S.; Fassina, A. Programmed cell death 4 and microRNA 21 inverse expression is maintained in cells and exosomes from ovarian serous carcinoma effusions: PDCD4 and miR-21 Expression in OSC and Exosomes. Cancer Cytopathol. 2014, 122, 685-693. [CrossRef] [PubMed]

112. Taylor, D.D.; Gercel-Taylor, C. MicroRNA signatures of tumor-derived exosomes as diagnostic biomarkers of ovarian cancer. Gynecol. Oncol. 2008, 110, 13-21. [CrossRef]

113. Yu, X.; Harris, S.L.; Levine, A.J. The Regulation of Exosome Secretion: A Novel Function of the p53 Protein. Cancer Res. 2006, 66, 4795-4801. [CrossRef] [PubMed] 
114. Xavier, C.P.R.; Caires, H.R.; Barbosa, M.A.G.; Bergantim, R.; Guimarães, J.E.; Vasconcelos, M.H. The Role of Extracellular Vesicles in the Hallmarks of Cancer and Drug Resistance. Cells 2020, 9, 1141. [CrossRef]

115. Graner, M.W.; Alzate, O.; Dechkovskaia, A.M.; Keene, J.D.; Sampson, J.H.; Mitchell, D.A.; Bigner, D.D. Proteomic and immunologic analyses of brain tumor exosomes. FASEB J. 2009, 23, 1541-1557. [CrossRef] [PubMed]

116. Webber, J.; Stone, T.C.; Katilius, E.; Smith, B.C.; Gordon, B.; Mason, M.D.; Tabi, Z.; Brewis, I.A.; Clayton, A. Proteomics Analysis of Cancer Exosomes Using a Novel Modified Aptamer-based Array (SOMAscan ${ }^{\mathrm{TM}}$ ) Platform. Mol. Cell Proteom. 2014, 13, 1050-1064. [CrossRef] [PubMed]

117. Welton, J.L.; Khanna, S.; Giles, P.J.; Brennan, P.; Brewis, I.A.; Staffurth, J.; Mason, M.D.; Clayton, A. Proteomics Analysis of Bladder Cancer Exosomes. Mol. Cell Proteom. 2010, 9, 1324-1338. [CrossRef] [PubMed]

118. Demory Beckler, M.; Higginbotham, J.N.; Franklin, J.L.; Ham, A.-J.; Halvey, P.J.; Imasuen, I.E.; Whitwell, C.; Li, M.; Liebler, D.C.; Coffey, R.J. Proteomic Analysis of Exosomes from Mutant KRAS Colon Cancer Cells Identifies Intercellular Transfer of Mutant KRAS. Mol. Cell Proteom. 2013, 12, 343-355. [CrossRef]

119. Soldevilla, B.; Rodríguez, M.; San Millán, C.; García, V.; Fernández-Periañez, R.; Gil-Calderón, B.; Martín, P.; García-Grande, A.; Silva, J.; Bonilla, F.; et al. Tumor-derived exosomes are enriched in $\Delta \mathrm{Np} 73$, which promotes oncogenic potential in acceptor cells and correlates with patient survival. Hum. Mol. Genet. 2014, 23, 467-478. [CrossRef]

120. Ohshima, K.; Inoue, K.; Fujiwara, A.; Hatakeyama, K.; Kanto, K.; Watanabe, Y.; Muramatsu, K.; Fukuda, Y.; Ogura, S.; Yamaguchi, K.; et al. Let-7 MicroRNA Family Is Selectively Secreted into the Extracellular Environment via Exosomes in a Metastatic Gastric Cancer Cell Line. PLoS ONE 2010, 5, e13247. [CrossRef]

121. Abd Elmageed, Z.Y.; Yang, Y.; Thomas, R.; Ranjan, M.; Mondal, D.; Moroz, K.; Fang, Z.; Rezk, B.M.; Moparty, K.; Sikka, S.C.; et al. Neoplastic Reprogramming of Patient-Derived Adipose Stem Cells by Prostate Cancer Cell-Associated Exosomes: Tumor Exosomes Trigger Stem Cell Transformation. Stem Cells 2014, 32, 983-997. [CrossRef]

122. Ostenfeld, M.S.; Jeppesen, D.K.; Laurberg, J.R.; Boysen, A.T.; Bramsen, J.B.; Primdal-Bengtson, B.; Hendrix, A.; Lamy, P.; Dagnaes-Hansen, F.; Rasmussen, M.H.; et al. Cellular Disposal of miR23b by RAB27-Dependent Exosome Release Is Linked to Acquisition of Metastatic Properties. Cancer Res. 2014, 74, 5758-5771. [CrossRef] [PubMed]

123. Putz, U.; Howitt, J.; Doan, A.; Goh, C.-P.; Low, L.-H.; Silke, J.; Tan, S.-S. The Tumor Suppressor PTEN Is Exported in Exosomes and Has Phosphatase Activity in Recipient Cells. Sci. Signal. 2012, 5, ra70. [CrossRef]

124. Meehan, K.; Vella, L.J. The contribution of tumour-derived exosomes to the hallmarks of cancer. Crit. Rev. Clin. Lab. Sci. 2016, 53, 121-131. [CrossRef]

125. Xiao, H.; Lässer, C.; Shelke, G.V.; Wang, J.; Rådinger, M.; Lunavat, T.R.; Malmhäll, C.; Lin, L.H.; Li, J.; $\mathrm{Li}$, L.; et al. Mast cell exosomes promote lung adenocarcinoma cell proliferation-Role of KIT-stem cell factor signaling. Cell Commun. Signal. 2014, 12, 64. [CrossRef]

126. Li, C. CD97 promotes gastric cancer cell proliferation and invasion through exosome-mediated MAPK signaling pathway. World J. Gastroenterol. WJG 2015, 21, 6215. [CrossRef] [PubMed]

127. Qu, J.-L.; Qu, X.-J.; Zhao, M.-F.; Teng, Y.-E.; Zhang, Y.; Hou, K.-Z.; Jiang, Y.-H.; Yang, X.-H.; Liu, Y.-P. Gastric cancer exosomes promote tumour cell proliferation through PI3K/Akt and MAPK/ERK activation. Dig. Liver Dis. 2009, 41, 875-880. [CrossRef] [PubMed]

128. Vella, L.J.; Behren, A.; Coleman, B.; Greening, D.W.; Hill, A.F.; Cebon, J. Intercellular Resistance to BRAF Inhibition Can Be Mediated by Extracellular Vesicle-Associated PDGFR $\beta$. Neoplasia 2017, 19, 932-940. [CrossRef]

129. Yang, L.; Wu, X.-H.; Wang, D.; Luo, C.-L.; Chen, L.-X. Bladder cancer cell-derived exosomes inhibit tumor cell apoptosis and induce cell proliferation in vitro. Mol. Med. Rep. 2013, 8, 1272-1278. [CrossRef] [PubMed]

130. Setti, M.; Osti, D.; Richichi, C.; Ortensi, B.; Del Bene, M.; Fornasari, L.; Beznoussenko, G.; Mironov, A.; Rappa, G.; Cuomo, A.; et al. Extracellular vesicle-mediated transfer of CLIC1 protein is a novel mechanism for the regulation of glioblastoma growth. Oncotarget 2015, 6, 31413-31427. [CrossRef]

131. The Australian Prostate Cancer Collaboration BioResource; Soekmadji, C.; Riches, J.D.; Russell, P.J.; Ruelcke, J.E.; McPherson, S.; Wang, C.; Hovens, C.M.; Corcoran, N.M.; Hill, M.M.; et al. Modulation of paracrine signaling by CD9 positive small extracellular vesicles mediates cellular growth of androgen deprived prostate cancer. Oncotarget 2017, 8, 52237-52255. [CrossRef] [PubMed] 
132. Matsumoto, A.; Takahashi, Y.; Nishikawa, M.; Sano, K.; Morishita, M.; Charoenviriyakul, C.; Saji, H.; Takakura, Y. Accelerated growth of B16 BL 6 tumor in mice through efficient uptake of their own exosomes by B16 BL 6 cells. Cancer Sci. 2017, 108, 1803-1810. [CrossRef]

133. Liu, M.X.; Liao, J.; Xie, M.; Gao, Z.K.; Wang, X.H.; Zhang, Y.; Shang, M.H.; Yin, L.H.; Pu, Y.P.; Liu, R. miR-93-5p Transferred by Exosomes Promotes the Proliferation of Esophageal Cancer Cells via Intercellular Communication by Targeting PTEN. Biomed. Environ. Sci. 2018, 31, 171-185. [CrossRef]

134. Teng, Y.; Ren, Y.; Hu, X.; Mu, J.; Samykutty, A.; Zhuang, X.; Deng, Z.; Kumar, A.; Zhang, L.; Merchant, M.L.; et al. MVP-mediated exosomal sorting of miR-193a promotes colon cancer progression. Nat. Commun. 2017, 8, 14448. [CrossRef]

135. Lee, J.C.; Zhao, J.-T.; Gundara, J.; Serpell, J.; Bach, L.A.; Sidhu, S. Papillary thyroid cancer-derived exosomes contain miRNA-146b and miRNA-222. J. Surg. Res. 2015, 196, 39-48. [CrossRef] [PubMed]

136. Graner, M.W.; Schnell, S.; Olin, M.R. Tumor-derived exosomes, microRNAs, and cancer immune suppression. Semin. Immunopathol. 2018, 40, 505-515. [CrossRef] [PubMed]

137. Lässer, C.; Théry, C.; Buzás, E.I.; Mathivanan, S.; Zhao, W.; Gho, Y.S.; Lötvall, J. The International Society for Extracellular Vesicles launches the first massive open online course on extracellular vesicles. J. Extracell. Vesicles 2016, 5, 34299. [CrossRef] [PubMed]

138. Kogure, T.; Lin, W.-L.; Yan, I.K.; Braconi, C.; Patel, T. Intercellular nanovesicle-mediated microRNA transfer: A mechanism of environmental modulation of hepatocellular cancer cell growth. Hepatology 2011, 54, 1237-1248. [CrossRef]

139. You, Y.; Shan, Y.; Chen, J.; Yue, H.; You, B.; Shi, S.; Li, X.; Cao, X. Matrix metalloproteinase 13-containing exosomes promote nasopharyngeal carcinoma metastasis. Cancer Sci. 2015, 106, 1669-1677. [CrossRef]

140. Ramteke, A.; Ting, H.; Agarwal, C.; Mateen, S.; Somasagara, R.; Hussain, A.; Graner, M.; Frederick, B.; Agarwal, R.; Deep, G. Exosomes secreted under hypoxia enhance invasiveness and stemness of prostate cancer cells by targeting adherens junction molecules: Hypoxic-exosomes role in pca aggressiveness. Mol. Carcinog. 2015, 54, 554-565. [CrossRef] [PubMed]

141. Franzen, C.A.; Blackwell, R.H.; Todorovic, V.; Greco, K.A.; Foreman, K.E.; Flanigan, R.C.; Kuo, P.C.; Gupta, G.N. Urothelial cells undergo epithelial-to-mesenchymal transition after exposure to muscle invasive bladder cancer exosomes. Oncogenesis 2015, 4, e163. [CrossRef] [PubMed]

142. Rahman, M.A.; Barger, J.F.; Lovat, F.; Gao, M.; Otterson, G.A.; Nana-Sinkam, P. Lung cancer exosomes as drivers of epithelial mesenchymal transition. Oncotarget 2016, 7, 54852-54866. [CrossRef] [PubMed]

143. Fabbri, M.; Paone, A.; Calore, F.; Galli, R.; Croce, C.M. A new role for microRNAs, as ligands of Toll-like receptors. RNA Biol. 2013, 10, 169-174. [CrossRef]

144. Kim, C.W.; Lee, H.M.; Lee, T.H.; Kang, C.; Kleinman, H.K.; Gho, Y.S. Extracellular membrane vesicles from tumor cells promote angiogenesis via sphingomyelin. Cancer Res. 2002, 62, 6312-6317. [PubMed]

145. Kholia, S.; Ranghino, A.; Garnieri, P.; Lopatina, T.; Deregibus, M.C.; Rispoli, P.; Brizzi, M.F.; Camussi, G. Extracellular vesicles as new players in angiogenesis. Vasc. Pharmacol. 2016, 86, 64-70. [CrossRef] [PubMed]

146. Lombardo, G.; Dentelli, P.; Togliatto, G.; Rosso, A.; Gili, M.; Gallo, S.; Deregibus, M.C.; Camussi, G.; Brizzi, M.F. Activated Stat 5 trafficking Via Endothelial Cell-derived Extracellular Vesicles Controls IL-3 Pro-angiogenic Paracrine Action. Sci. Rep. 2016, 6, 25689. [CrossRef] [PubMed]

147. van Balkom, B.W.M.; de Jong, O.G.; Smits, M.; Brummelman, J.; den Ouden, K.; de Bree, P.M.; van Eijndhoven, M.A.J.; Pegtel, D.M.; Stoorvogel, W.; Würdinger, T.; et al. Endothelial cells require miR-214 to secrete exosomes that suppress senescence and induce angiogenesis in human and mouse endothelial cells. Blood 2013, 121, 3997-4006. [CrossRef] [PubMed]

148. Teng, X.; Chen, L.; Chen, W.; Yang, J.; Yang, Z.; Shen, Z. Mesenchymal Stem Cell-Derived Exosomes Improve the Microenvironment of Infarcted Myocardium Contributing to Angiogenesis and Anti-Inflammation. Cell Physiol. Biochem. 2015, 37, 2415-2424. [CrossRef]

149. Zeng, Z.; Li, Y.; Pan, Y.; Lan, X.; Song, F.; Sun, J.; Zhou, K.; Liu, X.; Ren, X.; Wang, F.; et al. Cancer-derived exosomal miR-25-3p promotes pre-metastatic niche formation by inducing vascular permeability and angiogenesis. Nat. Commun. 2018, 9, 5395. [CrossRef]

150. Fang, J.; Zhang, Z.; Shang, L.; Luo, Y.; Lin, Y.; Yuan, Y.; Zhuang, S. Hepatoma cell-secreted exosomal microRNA-103 increases vascular permeability and promotes metastasis by targeting junction proteins. Hepatology 2018, 68, 1459-1475. [CrossRef] 
151. Lawson, J.; Dickman, C.; MacLellan, S.; Towle, R.; Jabalee, J.; Lam, S.; Garnis, C. Selective secretion of microRNAs from lung cancer cells via extracellular vesicles promotes CAMK1D-mediated tube formation in endothelial cells. Oncotarget 2017, 8, 83913-83924. [CrossRef] [PubMed]

152. Zhuang, G.; Wu, X.; Jiang, Z.; Kasman, I.; Yao, J.; Guan, Y.; Oeh, J.; Modrusan, Z.; Bais, C.; Sampath, D.; et al. Tumour-secreted miR-9 promotes endothelial cell migration and angiogenesis by activating the JAK-STAT pathway. EMBO J. 2012, 31, 3513-3523. [CrossRef]

153. Qu, J.; Lu, D.; Guo, H.; Miao, W.; Wu, G.; Zhou, M. MicroRNA-9 regulates osteoblast differentiation and angiogenesis via the AMPK signaling pathway. Mol. Cell. Biochem. 2016, 411, 23-33. [CrossRef] [PubMed]

154. Simon, T.; Pinioti, S.; Schellenberger, P.; Rajeeve, V.; Wendler, F.; Cutillas, P.R.; King, A.; Stebbing, J.; Giamas, G. Shedding of bevacizumab in tumour cells-derived extracellular vesicles as a new therapeutic escape mechanism in glioblastoma. Mol. Cancer 2018, 17, 132. [CrossRef] [PubMed]

155. Feng, Q.; Zhang, C.; Lum, D.; Druso, J.E.; Blank, B.; Wilson, K.F.; Welm, A.; Antonyak, M.A.; Cerione, R.A. A class of extracellular vesicles from breast cancer cells activates VEGF receptors and tumour angiogenesis. Nat. Commun. 2017, 8, 14450. [CrossRef]

156. Qu, Z.; Wu, J.; Wu, J.; Luo, D.; Jiang, C.; Ding, Y. Exosomes derived from HCC cells induce sorafenib resistance in hepatocellular carcinoma both in vivo and in vitro. J. Exp. Clin. Cancer Res. 2016, 35, 159. [CrossRef]

157. Takahashi, K.; Yan, I.K.; Kogure, T.; Haga, H.; Patel, T. Extracellular vesicle-mediated transfer of long non-coding RNA ROR modulates chemosensitivity in human hepatocellular cancer. FEBS Open Bio 2014, 4, 458-467. [CrossRef]

158. Stone, L. Exosome transmission of sunitinib resistance. Nat. Rev. Urol. 2016, 13, 297. [CrossRef]

159. Wieckowski, E.U.; Visus, C.; Szajnik, M.; Szczepanski, M.J.; Storkus, W.J.; Whiteside, T.L. Tumor-Derived Microvesicles Promote Regulatory T Cell Expansion and Induce Apoptosis in Tumor-Reactive Activated $\mathrm{CD}^{+}{ }^{+}$T Lymphocytes. J. Immunol. 2009, 183, 3720-3730. [CrossRef]

160. Vu, L.T.; Peng, B.; Zhang, D.X.; Ma, V.; Mathey-Andrews, C.A.; Lam, C.K.; Kiomourtzis, T.; Jin, J.; McReynolds, L.; Huang, L.; et al. Tumor-secreted extracellular vesicles promote the activation of cancer-associated fibroblasts via the transfer of microRNA-125b. J. Extracell. Vesicles 2019, 8, 1599680. [CrossRef]

161. Poggio, M.; Hu, T.; Pai, C.-C.; Chu, B.; Belair, C.D.; Chang, A.; Montabana, E.; Lang, U.E.; Fu, Q.; Fong, L.; et al. Suppression of Exosomal PD-L1 Induces Systemic Anti-tumor Immunity and Memory. Cell 2019, 177, 414-427.e13. [CrossRef] [PubMed]

162. Del Re, M.; Marconcini, R.; Pasquini, G.; Rofi, E.; Vivaldi, C.; Bloise, F.; Restante, G.; Arrigoni, E.; Caparello, C.; Bianco, M.G.; et al. PD-L1 mRNA expression in plasma-derived exosomes is associated with response to anti-PD-1 antibodies in melanoma and NSCLC. Br. J. Cancer 2018, 118, 820-824. [CrossRef] [PubMed]

163. Theodoraki, M.-N.; Yerneni, S.; Gooding, W.E.; Ohr, J.; Clump, D.A.; Bauman, J.E.; Ferris, R.L.; Whiteside, T.L. Circulating exosomes measure responses to therapy in head and neck cancer patients treated with cetuximab, ipilimumab, and IMRT. OncoImmunology 2019, 8, e1593805. [CrossRef] [PubMed]

164. Yen, E.-Y.; Miaw, S.-C.; Yu, J.-S.; Lai, I.-R. Exosomal TGF- $\beta 1$ is correlated with lymphatic metastasis of gastric cancers. Am. J. Cancer Res. 2017, 7, 2199-2208.

165. Que, R.; Lin, C.; Ding, G.; Wu, Z.; Cao, L. Increasing the immune activity of exosomes: The effect of miRNA-depleted exosome proteins on activating dendritic cell/cytokine-induced killer cells against pancreatic cancer. J. Zhejiang Univ. Sci. B 2016, 17, 352-360. [CrossRef]

166. Feitelson, M.A.; Arzumanyan, A.; Kulathinal, R.J.; Blain, S.W.; Holcombe, R.F.; Mahajna, J.; Marino, M.; Martinez-Chantar, M.L.; Nawroth, R.; Sanchez-Garcia, I.; et al. Sustained proliferation in cancer: Mechanisms and novel therapeutic targets. Semin. Cancer Biol. 2015, 35, S25-S54. [CrossRef]

167. Yin, Y.; Cai, X.; Chen, X.; Liang, H.; Zhang, Y.; Li, J.; Wang, Z.; Chen, X.; Zhang, W.; Yokoyama, S.; et al. Tumor-secreted miR-214 induces regulatory T cells: A major link between immune evasion and tumor growth. Cell Res. 2014, 24, 1164-1180. [CrossRef]

168. Cesi, G.; Philippidou, D.; Kozar, I.; Kim, Y.J.; Bernardin, F.; Van Niel, G.; Wienecke-Baldacchino, A.; Felten, P.; Letellier, E.; Dengler, S.; et al. A new ALK isoform transported by extracellular vesicles confers drug resistance to melanoma cells. Mol. Cancer 2018, 17, 145. [CrossRef]

169. Kalra, H.; Gangoda, L.; Fonseka, P.; Chitti, S.V.; Liem, M.; Keerthikumar, S.; Samuel, M.; Boukouris, S.; Al Saffar, H.; Collins, C.; et al. Extracellular vesicles containing oncogenic mutant $\beta$-catenin activate Wnt signalling pathway in the recipient cells. J. Extracell. Vesicles 2019, 8, 1690217. [CrossRef] 
170. Yadav, A.K.; Desai, N.S. Cancer Stem Cells: Acquisition, Characteristics, Therapeutic Implications, Targeting Strategies and Future Prospects. Stem Cell Rev. Rep. 2019, 15, 331-355. [CrossRef]

171. Wang, L.; Yang, G.; Zhao, D.; Wang, J.; Bai, Y.; Peng, Q.; Wang, H.; Fang, R.; Chen, G.; Wang, Z.; et al. CD103-positive CSC exosome promotes EMT of clear cell renal cell carcinoma: Role of remote MiR-19b-3p. Mol. Cancer 2019, 18, 86. [CrossRef] [PubMed]

172. Sun, Z.; Wang, L.; Dong, L.; Wang, X. Emerging role of exosome signalling in maintaining cancer stem cell dynamic equilibrium. J. Cell Mol. Med. 2018, 22, 3719-3728. [CrossRef] [PubMed]

173. Gabrusiewicz, K.; Li, X.; Wei, J.; Hashimoto, Y.; Marisetty, A.L.; Ott, M.; Wang, F.; Hawke, D.; Yu, J.; Healy, L.M.; et al. Glioblastoma stem cell-derived exosomes induce M2 macrophages and PD-L1 expression on human monocytes. OncoImmunology 2018, 7, e1412909. [CrossRef]

174. Hardin, H.; Helein, H.; Meyer, K.; Robertson, S.; Zhang, R.; Zhong, W.; Lloyd, R.V. Thyroid cancer stem-like cell exosomes: Regulation of EMT via transfer of lncRNAs. Lab. Invest. 2018, 98, 1133-1142. [CrossRef] [PubMed]

175. Hwang, W.-L.; Lan, H.-Y.; Cheng, W.-C.; Huang, S.-C.; Yang, M.-H. Tumor stem-like cell-derived exosomal RNAs prime neutrophils for facilitating tumorigenesis of colon cancer. J. Hematol. Oncol. 2019, 12, 10. [CrossRef]

176. Bouvy, C.; Wannez, A.; Laloy, J.; Chatelain, C.; Dogné, J.-M. Transfer of multidrug resistance among acute myeloid leukemia cells via extracellular vesicles and their microRNA cargo. Leuk. Res. 2017, 62, 70-76. [CrossRef] [PubMed]

177. Aung, T.; Chapuy, B.; Vogel, D.; Wenzel, D.; Oppermann, M.; Lahmann, M.; Weinhage, T.; Menck, K.; Hupfeld, T.; Koch, R.; et al. Exosomal evasion of humoral immunotherapy in aggressive B-cell lymphoma modulated by ATP-binding cassette transporter A3. Proc. Natl. Acad. Sci. USA 2011, 108, 15336-15341. [CrossRef]

178. Bebawy, M.; Combes, V.; Lee, E.; Jaiswal, R.; Gong, J.; Bonhoure, A.; Grau, G.E.R. Membrane microparticles mediate transfer of P-glycoprotein to drug sensitive cancer cells. Leukemia 2009, 23, 1643-1649. [CrossRef]

179. Lu, J.F.; Luk, F.; Gong, J.; Jaiswal, R.; Grau, G.E.R.; Bebawy, M. Microparticles mediate MRP1 intercellular transfer and the re-templating of intrinsic resistance pathways. Pharmacol. Res. 2013, 76, 77-83. [CrossRef] [PubMed]

180. Lu, J.F.; Pokharel, D.; Bebawy, M. A novel mechanism governing the transcriptional regulation of ABC transporters in MDR cancer cells. Drug Deliv. Transl. Res. 2017, 7, 276-285. [CrossRef]

181. Dong, Y.; Pan, Q.; Jiang, L.; Chen, Z.; Zhang, F.; Liu, Y.; Xing, H.; Shi, M.; Li, J.; Li, X.; et al. Tumor endothelial expression of P-glycoprotein upon microvesicular transfer of TrpC 5 derived from adriamycin-resistant breast cancer cells. Biochem. Biophys. Res. Commun. 2014, 446, 85-90. [CrossRef]

182. Zhang, Q.; Liu, R.-X.; Chan, K.-W.; Hu, J.; Zhang, J.; Wei, L.; Tan, H.; Yang, X.; Liu, H. Exosomal transfer of p-STAT3 promotes acquired 5-FU resistance in colorectal cancer cells. J. Exp. Clin. Cancer Res. 2019, 38, 320. [CrossRef] [PubMed]

183. Zhao, K.; Wang, Z.; Li, X.; Liu, J.; Tian, L.; Chen, J. Exosome-mediated transfer of CLIC1 contributes to the vincristine-resistance in gastric cancer. Mol. Cell Biochem. 2019, 462, 97-105. [CrossRef]

184. Gu, Y.Y.; Yu, J.; Zhang, J.F.; Wang, C. Suppressing the secretion of exosomal miR-19b by gw4869 could regulate oxaliplatin sensitivity in colorectal cancer. Neoplasma 2019, 66, 39-45. [CrossRef]

185. Ma, Y.; Yuwen, D.; Chen, J.; Zheng, B.; Gao, J.; Fan, M.; Xue, W.; Wang, Y.; Li, W.; Shu, Y.; et al. Exosomal Transfer Of Cisplatin-Induced miR-425-3p Confers Cisplatin Resistance In NSCLC Through Activating Autophagy. Int. J. Nanomed. 2019, 14, 8121-8132. [CrossRef]

186. Wu, H.; Zhou, J.; Mei, S.; Wu, D.; Mu, Z.; Chen, B.; Xie, Y.; Ye, Y.; Liu, J. Circulating exosomal microRNA-96 promotes cell proliferation, migration and drug resistance by targeting LMO7. J. Cell. Mol. Med. 2017, 21, 1228-1236. [CrossRef] [PubMed]

187. Wang, J.; Lv, B.; Su, Y.; Wang, X.; Bu, J.; Yao, L. Exosome-Mediated Transfer of lncRNA HOTTIP Promotes Cisplatin Resistance in Gastric Cancer Cells by Regulating HMGA1/miR-218 Axis. OncoTargets Therapy 2019, 12, 11325-11338. [CrossRef]

188. Cao, Y.-L.; Zhuang, T.; Xing, B.-H.; Li, N.; Li, Q. Exosomal DNMT1 mediates cisplatin resistance in ovarian cancer. Cell Biochem. Funct. 2017, 35, 296-303. [CrossRef] 
189. Akao, Y.; Khoo, F.; Kumazaki, M.; Shinohara, H.; Miki, K.; Yamada, N. Extracellular Disposal of Tumor-Suppressor miRs-145 and -34a via Microvesicles and 5-FU Resistance of Human Colon Cancer Cells. Int. J. Mol. Sci. 2014, 15, 1392-1401. [CrossRef]

190. Yu, D.; Wu, Y.; Zhang, X.; Lv, M.; Chen, W.; Chen, X.; Yang, S.; Shen, H.; Zhong, S.; Tang, J.; et al. Exosomes from adriamycin-resistant breast cancer cells transmit drug resistance partly by delivering miR-222. Tumor Biol. 2016, 37, 3227-3235. [CrossRef]

191. Wei, Y.; Lai, X.; Yu, S.; Chen, S.; Ma, Y.; Zhang, Y.; Li, H.; Zhu, X.; Yao, L.; Zhang, J. Exosomal miR-221/222 enhances tamoxifen resistance in recipient ER-positive breast cancer cells. Breast Cancer Res. Treat. 2014, 147, 423-431. [CrossRef] [PubMed]

192. Mikamori, M.; Yamada, D.; Eguchi, H.; Hasegawa, S.; Kishimoto, T.; Tomimaru, Y.; Asaoka, T.; Noda, T.; Wada, H.; Kawamoto, K.; et al. MicroRNA-155 Controls Exosome Synthesis and Promotes Gemcitabine Resistance in Pancreatic Ductal Adenocarcinoma. Sci. Rep. 2017, 7, 42339. [CrossRef]

193. de Souza, P.S.; Cruz, A.L.S.; Viola, J.P.B.; Maia, R.C. Microparticles induce multifactorial resistance through oncogenic pathways independently of cancer cell type. Cancer Sci. 2015, 106, 60-68. [CrossRef] [PubMed]

194. Yin, J.; Zeng, A.; Zhang, Z.; Shi, Z.; Yan, W.; You, Y. Exosomal transfer of miR-1238 contributes to temozolomide-resistance in glioblastoma. EBioMedicine 2019, 42, 238-251. [CrossRef] [PubMed]

195. Powers, M.P. The ever-changing world of gene fusions in cancer: A secondary gene fusion and progression. Oncogene 2019, 38, 7197-7199. [CrossRef]

196. Li, Q.; Zhong, Z.; Zeng, C.; Meng, L.; Li, C.; Luo, Y.; Wang, H.; Li, W.; Wang, J.; Cheng, F.; et al. A clinical observation of Chinese chronic myelogenous leukemia patients after discontinuation of tyrosine kinase inhibitors. Oncotarget 2016, 7. [CrossRef]

197. Kumar-Sinha, C.; Tomlins, S.A.; Chinnaiyan, A.M. Recurrent gene fusions in prostate cancer. Nat. Rev. Cancer 2008, 8, 497-511. [CrossRef]

198. Fujita, K.; Nonomura, N. Urinary biomarkers of prostate cancer. Int. J. Urol. 2018, 25, 770-779. [CrossRef]

199. Wong, C.-H.; Chen, Y.-C. Clinical significance of exosomes as potential biomarkers in cancer. World J. Clin. Cases 2019, 7, 171-190. [CrossRef]

200. Schey, K.L.; Luther, J.M.; Rose, K.L. Proteomics characterization of exosome cargo. Methods 2015, 87, 75-82. [CrossRef]

201. Mohammadi, S.; Yousefi, F.; Shabaninejad, Z.; Movahedpour, A.; Mahjoubin Tehran, M.; Shafiee, A.; Moradizarmehri, S.; Hajighadimi, S.; Savardashtaki, A.; Mirzaei, H. Exosomes and cancer: From oncogenic roles to therapeutic applications. IUBMB Life 2020, 72, 724-748. [CrossRef] [PubMed]

202. Luan, X.; Sansanaphongpricha, K.; Myers, I.; Chen, H.; Yuan, H.; Sun, D. Engineering exosomes as refined biological nanoplatforms for drug delivery. Acta Pharm. Sin. 2017, 38, 754-763. [CrossRef] [PubMed]

203. Liang, G.; Kan, S.; Zhu, Y.; Feng, S.; Feng, W.; Gao, S. Engineered exosome-mediated delivery of functionally active miR-26a and its enhanced suppression effect in HepG2 cells. Int. J. Nanomed. 2018, 13, 585-599. [CrossRef]

204. Vader, P.; Mol, E.A.; Pasterkamp, G.; Schiffelers, R.M. Extracellular vesicles for drug delivery. Adv. Drug Deliv. Rev. 2016, 106, 148-156. [CrossRef]

205. Li, Y.; Zheng, Q.; Bao, C.; Li, S.; Guo, W.; Zhao, J.; Chen, D.; Gu, J.; He, X.; Huang, S. Circular RNA is enriched and stable in exosomes: A promising biomarker for cancer diagnosis. Cell Res. 2015, 25, 981-984. [CrossRef]

206. Wiklander, O.P.B.; Nordin, J.Z.; O’Loughlin, A.; Gustafsson, Y.; Corso, G.; Mäger, I.; Vader, P.; Lee, Y.; Sork, H.; Seow, Y.; et al. Extracellular vesicle in vivo biodistribution is determined by cell source, route of administration and targeting. J. Extracell. Vesicles 2015, 4, 26316. [CrossRef] [PubMed]

207. Johnsen, K.B.; Gudbergsson, J.M.; Skov, M.N.; Pilgaard, L.; Moos, T.; Duroux, M. A comprehensive overview of exosomes as drug delivery vehicles-Endogenous nanocarriers for targeted cancer therapy. Biochim. Biophys. Acta (BBA) Rev. Cancer 2014, 1846, 75-87. [CrossRef]

208. Ma, J.; Zhang, Y.; Tang, K.; Zhang, H.; Yin, X.; Li, Y.; Xu, P.; Sun, Y.; Ma, R.; Ji, T.; et al. Reversing drug resistance of soft tumor-repopulating cells by tumor cell-derived chemotherapeutic microparticles. Cell Res. 2016, 26, 713-727. [CrossRef]

209. Parolini, I.; Federici, C.; Raggi, C.; Lugini, L.; Palleschi, S.; De Milito, A.; Coscia, C.; Iessi, E.; Logozzi, M.; Molinari, A.; et al. Microenvironmental pH Is a Key Factor for Exosome Traffic in Tumor Cells. J. Biol. Chem. 2009, 284, 34211-34222. [CrossRef] 
210. Kim, M.S.; Haney, M.J.; Zhao, Y.; Mahajan, V.; Deygen, I.; Klyachko, N.L.; Inskoe, E.; Piroyan, A.; Sokolsky, M.; Okolie, O.; et al. Development of exosome-encapsulated paclitaxel to overcome MDR in cancer cells. Nanomed. Nanotechnol. Biol. Med. 2016, 12, 655-664. [CrossRef]

211. Qiao, L.; Hu, S.; Huang, K.; Su, T.; Li, Z.; Vandergriff, A.; Cores, J.; Dinh, P.-U.; Allen, T.; Shen, D.; et al. Tumor cell-derived exosomes home to their cells of origin and can be used as Trojan horses to deliver cancer drugs. Theranostics 2020, 10, 3474-3487. [CrossRef] [PubMed]

212. Hao, D.; Li, Y.; Zhao, G.; Zhang, M. Soluble fms-like tyrosine kinase-1-enriched exosomes suppress the growth of small cell lung cancer by inhibiting endothelial cell migration. Thorac. Cancer 2019, 10, 1962-1972. [CrossRef] [PubMed]

213. Liu, T.; Zhang, X.; Du, L.; Wang, Y.; Liu, X.; Tian, H.; Wang, L.; Li, P.; Zhao, Y.; Duan, W.; et al. Exosome-transmitted miR-128-3p increase chemosensitivity of oxaliplatin-resistant colorectal cancer. Mol. Cancer 2019, 18, 43. [CrossRef] [PubMed]

214. Wan, F.-Z.; Chen, K.-H.; Sun, Y.-C.; Chen, X.-C.; Liang, R.-B.; Chen, L.; Zhu, X.-D. Exosomes overexpressing miR-34c inhibit malignant behavior and reverse the radioresistance of nasopharyngeal carcinoma. J. Transl. Med. 2020, 18, 12. [CrossRef]

215. Kobayashi, M.; Sawada, K.; Miyamoto, M.; Shimizu, A.; Yamamoto, M.; Kinose, Y.; Nakamura, K.; Kawano, M.; Kodama, M.; Hashimoto, K.; et al. Exploring the potential of engineered exosomes as delivery systems for tumor-suppressor microRNA replacement therapy in ovarian cancer. Biochem. Biophys. Res. Commun. 2020, 527, 153-161. [CrossRef]

216. Tian, H.; Li, W. Dendritic cell-derived exosomes for cancer immunotherapy: Hope and challenges. Ann. Transl. Med. 2017, 5, 221. [CrossRef]

217. Liu, C.; Guo, J.; Tian, F.; Yang, N.; Yan, F.; Ding, Y.; Wei, J.; Hu, G.; Nie, G.; Sun, J. Field-Free Isolation of Exosomes from Extracellular Vesicles by Microfluidic Viscoelastic Flows. ACS Nano 2017, 11, 6968-6976. [CrossRef]

218. Chen, T.; Arslan, F.; Yin, Y.; Tan, S.; Lai, R.; Choo, A.; Padmanabhan, J.; Lee, C.; de Kleijn, D.P.; Lim, S. Enabling a robust scalable manufacturing process for therapeutic exosomes through oncogenic immortalization of human ESC-derived MSCs. J. Transl. Med. 2011, 9, 47. [CrossRef]

219. Lener, T.; Gimona, M.; Aigner, L.; Börger, V.; Buzas, E.; Camussi, G.; Chaput, N.; Chatterjee, D.; Court, F.A.; del Portillo, H.A.; et al. Applying extracellular vesicles based therapeutics in clinical trials-An ISEV position paper. J. Extracell. Vesicles 2015, 4, 30087. [CrossRef]

220. Nie, W.; Wu, G.; Zhang, J.; Huang, L.; Ding, J.; Jiang, A.; Zhang, Y.; Liu, Y.; Li, J.; Pu, K.; et al. Responsive Exosome Nano-bioconjugates for Synergistic Cancer Therapy. Angew. Chem. Int. Ed. 2020, 59, 2018-2022. [CrossRef]

221. Yong, T.; Zhang, X.; Bie, N.; Zhang, H.; Zhang, X.; Li, F.; Hakeem, A.; Hu, J.; Gan, L.; Santos, H.A.; et al. Tumor exosome-based nanoparticles are efficient drug carriers for chemotherapy. Nat. Commun. 2019, 10, 3838. [CrossRef] [PubMed]

222. Bai, L.; Liu, Y.; Guo, K.; Zhang, K.; Liu, Q.; Wang, P.; Wang, X. Ultrasound Facilitates Naturally Equipped Exosomes Derived from Macrophages and Blood Serum for Orthotopic Glioma Treatment. ACS Appl. Mater. Interfaces 2019, 11, 14576-14587. [CrossRef]

223. Zhang, K.-L.; Wang, Y.-J.; Sun, J.; Zhou, J.; Xing, C.; Huang, G.; Li, J.; Yang, H. Artificial chimeric exosomes for anti-phagocytosis and targeted cancer therapy. Chem. Sci. 2019, 10, 1555-1561. [CrossRef]

224. Pomatto, M.A.C.; Bussolati, B.; D’Antico, S.; Ghiotto, S.; Tetta, C.; Brizzi, M.F.; Camussi, G. Improved Loading of Plasma-Derived Extracellular Vesicles to Encapsulate Antitumor miRNAs. Mol. Ther. Methods Clin. Dev. 2019, 13, 133-144. [CrossRef] [PubMed]

225. Gomari, H.; Forouzandeh Moghadam, M.; Soleimani, M. Targeted cancer therapy using engineered exosome as a natural drug delivery vehicle. OncoTargets Therapy 2018, 11, 5753-5762. [CrossRef] [PubMed]

226. Limoni, S.K.; Moghadam, M.F.; Moazzeni, S.M.; Gomari, H.; Salimi, F. Engineered Exosomes for Targeted Transfer of siRNA to HER2 Positive Breast Cancer Cells. Appl. Biochem. Biotechnol. 2019, 187, 352-364. [CrossRef]

227. O’Brien, K.P.; Khan, S.; Gilligan, K.E.; Zafar, H.; Lalor, P.; Glynn, C.; O’Flatharta, C.; Ingoldsby, H.; Dockery, P.; De Bhulbh, A.; et al. Employing mesenchymal stem cells to support tumor-targeted delivery of extracellular vesicle (EV)-encapsulated microRNA-379. Oncogene 2018, 37, 2137-2149. [CrossRef] 
228. Kim, M.S.; Haney, M.J.; Zhao, Y.; Yuan, D.; Deygen, I.; Klyachko, N.L.; Kabanov, A.V.; Batrakova, E.V. Engineering macrophage-derived exosomes for targeted paclitaxel delivery to pulmonary metastases: In vitro and in vivo evaluations. Nanomed. Nanotechnol. Biol. Med. 2018, 14, 195-204. [CrossRef]

229. Kamerkar, S.; LeBleu, V.S.; Sugimoto, H.; Yang, S.; Ruivo, C.F.; Melo, S.A.; Lee, J.J.; Kalluri, R. Exosomes facilitate therapeutic targeting of oncogenic KRAS in pancreatic cancer. Nature 2017, 546, 498-503. [CrossRef]

230. Bellavia, D.; Raimondo, S.; Calabrese, G.; Forte, S.; Cristaldi, M.; Patinella, A.; Memeo, L.; Manno, M.; Raccosta, S.; Diana, P.; et al. Interleukin 3-receptor targeted exosomes inhibit in vitro and in vivo Chronic Myelogenous Leukemia cell growth. Theranostics 2017, 7, 1333-1345. [CrossRef]

231. Morishita, M.; Takahashi, Y.; Matsumoto, A.; Nishikawa, M.; Takakura, Y. Exosome-based tumor antigens-adjuvant co-delivery utilizing genetically engineered tumor cell-derived exosomes with immunostimulatory CpG DNA. Biomaterials 2016, 111, 55-65. [CrossRef] [PubMed]

232. Tian, Y.; Li, S.; Song, J.; Ji, T.; Zhu, M.; Anderson, G.J.; Wei, J.; Nie, G. A doxorubicin delivery platform using engineered natural membrane vesicle exosomes for targeted tumor therapy. Biomaterials 2014, 35, 2383-2390. [CrossRef] [PubMed]

233. Ohno, S.; Takanashi, M.; Sudo, K.; Ueda, S.; Ishikawa, A.; Matsuyama, N.; Fujita, K.; Mizutani, T.; Ohgi, T.; Ochiya, T.; et al. Systemically Injected Exosomes Targeted to EGFR Deliver Antitumor MicroRNA to Breast Cancer Cells. Mol. Ther. 2013, 21, 185-191. [CrossRef] [PubMed]

Publisher's Note: MDPI stays neutral with regard to jurisdictional claims in published maps and institutional affiliations. 